\title{
29. MAGNETIC PROPERTIES OF IGNEOUS ROCKS FROM DEEP SEA DRILLING PROJECT LEG 631
}

\author{
Surendra Pal Verma, ${ }^{2}$ Instituto de Geofisica, Universidad Nacional Autónoma de Mexico, \\ Ciudad Universitaria, Mexico 20, D.F., Mexico, \\ and
}

Subir K. Banerjee, Department of Geology and Geophysics, University of Minnesota, Minneapolis, Minnesota

\section{INTRODUCTION}

This study reports the magnetic properties of 30 samples of igneous rocks recovered from Sites 469 through 473 of Leg 63 of the Deep Sea Drilling Project. Such studies are relevant for determining the thickness and composition of the source layer of the marine magnetic anomalies. These studies are also relevant to the study of ophiolites, in which direct comparison of magnetic properties can lead to important inferences (e.g., Butler et al., 1976; Levi et al., 1978; Beske-Diehl and Banerjee, 1979).

We made routine measurements of paleomagnetism on all samples. The magnetic properties reported here include the following:

1) Intensity and stability of natural remanent magnetization (NRM).

2) Intensity and stability of anhysteretic remanent magnetization (ARM).

3) Intensity and stability of viscous remanent magnetization (VRM).

4) Saturation magnetization $\left(M_{s}\right)$.

5) Hysteresis parameters, i.e., saturation remanent magnetization $\left(M_{r}\right)$, the ratio $\left(M_{r} / M_{S}\right)$ of saturation remanent magnetization to saturation magnetization, coercive force $\left(H_{c}\right)$, remanent coercive force $\left(H_{c r}\right)$, and initial and high-field susceptibilities $\left(\chi_{i}\right.$ and $\left.\chi_{p}\right)$.

6) Weak-field susceptibility $(\chi)$.

7) Thermomagnetic properties, i.e., Curie temperature $\left(T_{c}\right)$ and thermomagnetic curve characteristics.

\section{EXPERIMENTAL METHODS}

We measured the intensity and stability of NRM, ARM, and VRM on a Schonstedt spinner magnetometer coupled to a Hewlett-Packard computer and a Schönstedt single-axis alternating field demagnetizer. For the acquisition of ARM we applied a 1000-oe alternating field $(\widetilde{\mathrm{H}})$ in the presence of a steady 1 -oe direct field $(\overrightarrow{\mathrm{H}})$ and then reduced the alternating field (A.F.) slowly to zero oe. We then normalized the measured ARM intensity to 0.5 oe by dividing the measured value by 2; this was done so that the NRM and ARM intensities could be compared. We studied the acquisition of VRM in all samples by monitoring the magnetization acquired in 0.5 oe direct field for periods ranging from 15,000 to $28,800 \mathrm{~min}$. For each sample we made 10 or more measurements of remanence and computed the VRM component.

${ }^{1}$ Initial Reports of the Deep Sea Drilling Project, Volume 63. The experimental work for this study was done at the Department of Geology and Geophysics, University of Minnesota, when the first author (SPV) was visiting there.

${ }^{2}$ Earlier publications of this author are under the name of Surendra Pal.
We obtained hysteresis loops and thermomagnetic properties for each sample using a modified Princeton Applied Research vibrating sample magnetometer. The samples were heated in a vacuum. For weak-field susceptibility we employed a Bison susceptibility bridge.

\section{RESULTS}

Tables 1 and 2 give the results of magnetic measurements for individual samples, and Tables 3 and 4 present the average properties.

Natural Remanent Magnetization: $J_{n}, I, M D F_{n}$

NRM intensities $\left(J_{n}\right)$ of these samples range from 0.031 to $24.5 \times 10^{-3} \mathrm{emu} \mathrm{cm}^{-3}$, a range of about three orders of magnitude. Wide variations in $J_{n}$ are commonly observed in DSDP and dredged igneous rocks (e.g., Lowrie, 1974; Petersen, 1978; Marshall, 1978; Hamano et al., 1979). Our values are comparable to those previously reported for DSDP basalts but are somewhat lower than typical values for dredged basalts (Lowrie et al., 1973).

We used alternating-field demagnetization in progressively higher fields to investigate the stability of the NRM of each specimen. Figure 1 gives typical demagnetization curves. Also included are the demagnetization curves of ARM and VRM for the same samples.

Considerably high $M D F_{n}$ values (median destructive field for NRM) are characteristic of the NRM of basalts from Hole 470A and Site 472. The $M D F_{n}$ for the basalts from Sites 469 and 470 are somewhat lower, whereas the diabases from Sites 469,471 , and 473 consistently show relatively much lower $M D F_{n}$ values. This relationship is readily apparent in the data presented in Table 3, showing average magnetic properties for the different rock types at Leg 63 sites. $J_{n}$ values (intensity of natural remanent magnetism) also indicate a somewhat similar relationship, in that the basalts have higher $J_{n}$ than do the diabases, with the exception of Site 473 diabases (which show rather high NRM intensities). Site 473 is drilled on a much younger crust $(\sim 6.5 \mathrm{Ma})$, compared to the other sites $(\sim 14.5-17 \mathrm{Ma})$. These observations about $J_{n}$ and $M D F_{n}$ are, in general, consistent with grain sizes, as the basalts are fine-grained compared to the diabases.

By far the largest within-site variation in $J_{n}$ is observed in Site 471 diabases. This might reflect the "altered" nature of these diabases. An apparent inverse 
Table 1. Magnetization characteristics of Leg 63 igneous rocks.

\begin{tabular}{|c|c|c|c|c|c|c|c|c|c|c|c|c|c|c|c|c|c|}
\hline $\begin{array}{c}\begin{array}{c}\text { Sample } \\
\text { (interval in } \mathrm{cm} \text { ) }\end{array} \\
\end{array}$ & $J_{n}$ & $I$ & $J_{a}$ & $J_{v n}$ & $J_{\nu}$ & $\begin{array}{l}J_{\text {yex }}^{c} ; \\
J_{\text {vnex }}\end{array}$ & $M D F_{n}$ & $M D F_{n v}$ & $M D F_{a}$ & $M D F_{\mathrm{v}}{ }^{\mathrm{d}}$ & $J_{a} / J_{n}$ & $\begin{array}{l}J_{\text {vex }} / J_{n} \\
J_{\text {vnex }} / J_{n}\end{array}$ & $M D F_{a} / M D F_{n}$ & $M D F_{v} / M D F_{n}$ & $x$ & $Q_{n}^{\prime}$ & $Q_{n}$ \\
\hline \multicolumn{18}{|l|}{ Hole 469} \\
\hline $\begin{array}{l}\text { 40-1, 109-111 } \\
\text { diabase }\end{array}$ & $0.392^{\mathrm{a}}$ & +18 & 1.13 & & $\begin{array}{r}0.245 \\
(18200)\end{array}$ & 0.41 & 41 & & 36 & 8.8 & 2.9 & 1.0 & 0.9 & 0.2 & 16 & 0.025 & 0.054 \\
\hline $\begin{array}{l}41-3,62-64 \\
\text { diabase }\end{array}$ & 0.262 & +17 & 1.43 & $\begin{array}{l}0.286 \\
(20900)\end{array}$ & $\begin{array}{r}0.246 \\
(15000)\end{array}$ & 0.32 & & 47 & 58 & 22 & 5.5 & $\begin{array}{l}1.2 \\
1.3\end{array}$ & 1.2 & 0.5 & 22 & 0.012 & 0.026 \\
\hline $\begin{array}{l}42-4,66-68 \\
\text { diabase }\end{array}$ & 0.714 & -5 & 1.54 & & $\begin{array}{r}0.326 \\
(22600)\end{array}$ & 0.44 & 70 & & 45 & 10.8 & 2.2 & 0.6 & 0.6 & 0.2 & 17 & 0.042 & 0.093 \\
\hline $\begin{array}{l}42-5,76-78 \\
\text { diabase }\end{array}$ & 0.615 & -3 & 1.41 & & $\begin{array}{r}0.309 \\
(18200)\end{array}$ & 0.37 & 71 & & 51 & 22 & 2.3 & 0.6 & 0.7 & 0.3 & 17 & 0.036 & 0.080 \\
\hline $\begin{array}{l}42-6,21-23 \\
\text { diabase }\end{array}$ & 0.664 & unor. & 1.72 & & $\begin{array}{r}0.382 \\
(22600)\end{array}$ & 0.52 & 92 & & 67 & 17 & 2.6 & 0.8 & 0.7 & 0.2 & 23 & 0.029 & 0.064 \\
\hline $\begin{array}{l}44-3,13-15 \\
\text { basalt }\end{array}$ & $2.73^{\mathrm{a}}$ & -7 & 6.30 & & $\begin{array}{r}0.764 \\
(22700)\end{array}$ & 1.0 & 125 & & 134 & 38 & 2.3 & 0.4 & 1.1 & 0.3 & 36 & 0.076 & 0.17 \\
\hline $\begin{array}{l}45-2,114-116 \\
\text { basalt }\end{array}$ & 1.54 & +8 & 7.45 & & $\begin{array}{r}0.549 \\
(20400)\end{array}$ & 0.63 & 151 & & 134 & 81 & 4.8 & 0.4 & 0.9 & 0.5 & 35 & 0.044 & 0.098 \\
\hline $\begin{array}{l}46-2,23-25 \\
\text { basalt }\end{array}$ & 0.680 & +25 & 4.08 & $\begin{array}{l}0.228 \\
(20900)\end{array}$ & $\begin{array}{r}0.220 \\
(15000)\end{array}$ & $\begin{array}{l}0.29 \\
0.39\end{array}$ & & 115 & 147 & 104 & 6.0 & $\begin{array}{l}0.4 ; \\
0.6\end{array}$ & 1.3 & 0.9 & 21 & 0.032 & 0.072 \\
\hline $\begin{array}{l}49-1,40-42 \\
\text { basalt }\end{array}$ & 2.42 & unst. & 3.52 & & $\begin{array}{r}0.540 \\
(22700)\end{array}$ & 0.74 & 134 & & 164 & 62 & 1.5 & 0.3 & 1.2 & 0.5 & 22 & 0.11 & 0.24 \\
\hline \multicolumn{18}{|l|}{ Hole 470} \\
\hline $\begin{array}{l}18-2,102-104 \\
\text { basalt }\end{array}$ & $24.5^{\mathrm{a}}$ & +23 & 6.25 & & $\begin{array}{r}0.226 \\
(22700)\end{array}$ & $=0.5$ & 308 & & 297 & 360 & 0.3 & 0.01 & 1.0 & 1.2 & 5.5 & 4.5 & 9.9 \\
\hline $\begin{array}{l}18-3,4-6 \\
\text { basalt }\end{array}$ & 5.55 & -18 & 3.28 & & $\begin{array}{r}0.102 \\
(22700)\end{array}$ & 0.14 & 298 & & 256 & 110 & 0.6 & 0.03 & 0.9 & 0.4 & 6.9 & 0.80 & 1.8 \\
\hline \multicolumn{18}{|l|}{ Hole 470A } \\
\hline $\begin{array}{l}7-1,138-140 \\
\text { basalt }\end{array}$ & 12.0 & -34 & 1.74 & $\begin{array}{l}0.5 \\
(23300)\end{array}$ & $\begin{array}{c}0.06 \\
(16000)\end{array}$ & $\begin{array}{l}- \\
-\end{array}$ & & 850 & 623 & - & 0.1 & $-;$ & 0.7 & - & 1.8 & 6.7 & 14.8 \\
\hline $\begin{array}{l}7-3,76-78 \\
\text { basalt }\end{array}$ & 13.7 & -39 & 2.49 & & $\begin{array}{c}0.1 \\
(16000)\end{array}$ & - & 494 & & 483 & - & 0.2 & - & 1.0 & - & 4.4 & 3.1 & 6.9 \\
\hline $\begin{array}{l}8-1,104-108 \\
\text { basalt "fresh", }\end{array}$ & 6.52 & $\begin{array}{l}\text { unor. } \\
(-22 \text { to } \\
-23)\end{array}$ & 0.920 & & $\begin{array}{l}=0.1 \\
(10500)\end{array}$ & - & $>1000$ & & 694 & - & 0.1 & - & $<0.7$ & - & 2.2 & 3.0 & 6.6 \\
\hline $\begin{array}{l}8-1,104-108 \\
\text { basalt } \\
\text { "oxidized" }\end{array}$ & 4.48 & $\begin{array}{l}\text { unor. } \\
(-15 \text { to } \\
-18)\end{array}$ & 0.835 & & $\begin{array}{l}=0.01 \\
(10500)\end{array}$ & - & 828 & & 619 & - & 0.2 & - & 0.7 & - & 1.6 & 2.8 & 6.2 \\
\hline $\begin{array}{l}8-2,84-86 \\
\text { basalt }\end{array}$ & 3.16 & -52 & 1.64 & & $\begin{array}{r}0.083 \\
(11000)\end{array}$ & - & 541 & & 424 & - & 0.5 & - & 0.8 & - & 1.8 & 1.8 & 3.9 \\
\hline $\begin{array}{l}9-4,96-98 \\
\text { basalt }\end{array}$ & 7.76 & -45 & 1.74 & & $\begin{array}{r}0.084 \\
(11000)\end{array}$ & - & 669 & & 525 & - & 0.2 & - & 0.8 & - & 1.8 & 4.3 & 9.6 \\
\hline \multicolumn{18}{|l|}{ Hole 471} \\
\hline $\begin{array}{l}79-1,118-120 \\
\text { diabase-altered }\end{array}$ & 0.031 & +36 & 0.114 & & $\begin{array}{c}0.0012 \\
(20400)\end{array}$ & 0.011 & 201 & & 405 & 80 & 3.7 & 0.4 & 2.0 & 0.4 & 1.4 & 0.022 & 0.049 \\
\hline $\begin{array}{l}84-1,40-42 \\
\text { diabase-altered }\end{array}$ & $0.392^{\mathrm{a}}$ & +35 & 2.07 & & $\begin{array}{r}0.334 \\
(20400)\end{array}$ & 0.41 & 149 & & 93 & 43 & 5.3 & 1.0 & 0.6 & 0.3 & 35 & 0.011 & 0.025 \\
\hline $\begin{array}{l}86-1,18-20 \\
\text { diabase-altered }\end{array}$ & $\left.\begin{array}{l}0.986 \\
0.980\end{array}\right\}^{b}$ & +44 & 1.11 & & $\begin{array}{r}0.183 \\
(20400)\end{array}$ & 0.27 & 94 & & 98 & 10 & 1.1 & 0.3 & 1.0 & 0.1 & 27 & 0.036 & 0.081 \\
\hline $\begin{array}{l}88-3,82-84 \\
\text { diabase-altered }\end{array}$ & 0.054 & unst. & 0.228 & $\begin{array}{l}0.0356 \\
(23400)\end{array}$ & $\begin{array}{c}0.0343 \\
(25000)\end{array}$ & $\begin{array}{l}0.081 \\
0.067\end{array}$ & & 88 & 104 & 18 & 4.2 & $\begin{array}{l}1.5 ; \\
1.2\end{array}$ & 1.2 & 0.2 & 10 & 0.005 & 0.012 \\
\hline \multicolumn{18}{|l|}{ Hole 472} \\
\hline $\begin{array}{l}14-1,145-150 \\
\text { "core" basalt }\end{array}$ & 2.38 & unor. & 2.22 & & $\overline{(28800)}$ & - & 563 & & 387 & - & 0.9 & - & 0.7 & - & 2.3 & 1.0 & 2.3 \\
\hline $\begin{array}{l}14-1,145-150 \\
\text { "margin" basalt }\end{array}$ & 2.72 & unor. & 1.61 & & $(28800)$ & - & 732 & & 424 & - & 0.6 & - & 0.6 & - & 2.1 & 1.3 & 2.9 \\
\hline $\begin{array}{l}16-1,45-51 \\
\text { basalt }\end{array}$ & 3.85 & +17 & 3.04 & & $\begin{array}{r}0.056 \\
(28800)\end{array}$ & $=0.08$ & 372 & & 239 & $=250$ & 0.8 & 0.02 & 0.6 & $=0.7$ & 1.6 & 2.4 & 5.3 \\
\hline $\begin{array}{l}16-2,62-64 \\
\text { basalt }\end{array}$ & $\left.\begin{array}{l}1.82 \\
1.84\end{array}\right\}^{\mathrm{b}}$ & +15 & 2.12 & & $\begin{array}{r}0.027 \\
(20400)\end{array}$ & $=0.04$ & 631 & & 343 & - & 1.2 & 0.02 & 0.5 & - & 1.5 & 1.2 & 2.7 \\
\hline \multicolumn{18}{|l|}{ Hole 473} \\
\hline $\begin{array}{l}32-1,77-84 \\
\text { ('b' spec.) } \\
\text { diabase }\end{array}$ & 4.10 & unst. & $\begin{array}{l}7.800^{\mathrm{b}} \\
7.80^{\circ}\end{array}$ & & $\begin{array}{c}1.31 \\
(28800)\end{array}$ & 1.6 & 128 & & $\left.\begin{array}{l}31 \\
31\end{array}\right\}^{b}$ & 9.2 & 1.9 & 0.4 & 0.2 & 0.1 & 27 & 0.15 & 0.34 \\
\hline $\begin{array}{l}32-3,76-84 \\
\text { ('a' spec.) } \\
\text { diabase }\end{array}$ & 2.38 & unst. & 6.80 & & $\begin{array}{r}0.963 \\
(28800)\end{array}$ & 1.9 & 42 & & 20 & 7.4 & 2.9 & 0.8 & 0.5 & 0.2 & 40 & 0.060 & 0.13 \\
\hline $\begin{array}{l}33-1,66-74 \\
\text { ('a' spec.) } \\
\text { diabase }\end{array}$ & 3.26 & unst. & $\begin{array}{l}9.300^{\mathrm{b}} \\
9.50^{-}\end{array}$ & $\begin{array}{l}1.80 \\
(23300)\end{array}$ & $\begin{array}{c}2.04 \\
(28800)\end{array}$ & $\begin{array}{l}2.5 ; \\
2.4\end{array}$ & & 49 & $\left.\begin{array}{l}26 \\
23\end{array}\right\}^{b}$ & 7.6 & 2.9 & $\begin{array}{l}0.8 ; \\
0.7\end{array}$ & 0.5 & 0.2 & 53 & 0.062 & 0.14 \\
\hline $\begin{array}{l}33-1,66-74 \\
\text { ('b' spec.) } \\
\text { diabase }\end{array}$ & 4.10 & $\begin{array}{l}\text { shal. } \\
\text { inc. }\end{array}$ & 8.85 & & $\begin{array}{c}1.77 \\
(18200)\end{array}$ & 2.7 & 36 & & 24 & 10 & 2.2 & 0.7 & 0.7 & 0.3 & 54 & 0.076 & 0.17 \\
\hline $\begin{array}{l}34-3,10-17 \\
\text { diabase }\end{array}$ & 6.38 & unst. & 9.55 & & $\begin{array}{c}1.65 \\
(18200)\end{array}$ & 2.3 & 40 & & 21 & 7.9 & 1.5 & 0.4 & 0.5 & 0.2 & 53 & 0.12 & 0.27 \\
\hline $\begin{array}{l}\text { Note: } J_{n} \text { is intensity } \\
\mathrm{cm}{ }_{3} ; J_{v n} \text { is inte } \\
\text { in } 10-3 \mathrm{cmu} \mathrm{cm} \\
\text { quired on } \mathrm{Z}_{\mathrm{NRM}} \\
\text { VRM, in oe; } \chi \text { is } \\
\text { shal. inc. }=\text { shall } \\
\text { a This NRM intensity } \\
\text { b Data obtained in d } \\
\text { c No data was used f } \\
\text { d - in this column s }\end{array}$ & $\begin{array}{l}\text { f natural re } \\
\text { sity of vise } \\
3 \text { (time of a } \\
\text { in } 10^{-3} \mathrm{en} \\
\text { eak-field su } \\
w \text { inclinatio } \\
\left(J_{n} \text { ) has be }\right. \\
\text { plicate run } \\
\text { or extrapola } \\
\text { ands for di }\end{array}$ & $\begin{array}{l}\text { emanent me } \\
\text { cous remane } \\
\text { icquisition } \\
\text { mu cm }{ }^{-3} \text {; } \\
\text { usceptibility } \\
\text { on; spec. } \\
\text { een correcte } \\
\text { is and show } \\
\text { ation if the }\end{array}$ & $\begin{array}{l}\text { specim } \\
\text { ed for a } \\
\text { correlad }\end{array}$ & $\begin{array}{l}\text { ion (NRI } \\
\text { etization } \\
\text { nderneat: } \\
\text { median } \\
3 \text { emu cm } \\
\text { en (subse } \\
\text { small ant } \\
\text { ucibiltiy } \\
\text { ion coeff }\end{array}$ & $\begin{array}{l}\mathrm{n} 10^{-3} \mathrm{en} \\
2 \mathrm{M}) \text { acqui } \\
\text { parenthesi } \\
\text { ructive fie } \\
\mathrm{oe}^{-1} ; Q \text {, } \\
\text { e). } \\
\text { allel magr } \\
\text { neasureme } \\
\text { to of VRM }\end{array}$ & $\begin{array}{l}\min \text {; } \\
\text { or } \mathrm{NK} \\
\text { modi } \\
\text { com } \\
\text { sus } \mathrm{t}\end{array}$ & $\begin{array}{l}\text { oe; } \\
\text { oenig } \\
\text { ot pre } \\
\text { less }\end{array}$ & 0.8 & ted in : & $\begin{array}{l}a \text {, and } M L \\
\text { nally } Q_{n} \text { is } \\
\text { his column }\end{array}$ & $\begin{array}{l}F_{y} \text { ar } \\
\text { Koen }\end{array}$ & $\begin{array}{l}\text { ensity of a } \\
\text { mu } \mathrm{cm}^{-3} \\
\text { ale) extra } \\
\text { pectively, } \\
\text { ger ratio, }\end{array}$ & $\begin{array}{l}\text { Anhysteritic reman } \\
J_{y} \text { is intensity of } \\
\text { polated for } 105 \mathrm{~m} \\
\text { median destructi } \\
J_{n} / 0.45 x \text {. Lastly, }\end{array}$ & $\begin{array}{l}\text { nent magnetizat } \\
\text { fRM acquired } \\
\text { an, while } J_{\text {vnex }} \\
\text { ve fields for NF } \\
\text { unor. = unori }\end{array}$ & (AF & $\begin{array}{l}\mathrm{M}, \mathrm{A} \\
\mathrm{st} .=\end{array}$ & $\begin{array}{l}\text { emu } \\
\text { ample } \\
\text { M ac- } \\
\text { tand and } \\
\text { table; }\end{array}$ \\
\hline
\end{tabular}

correlation of their $J_{n}$ and $M D F_{n}$ values may be related to the degree of alteration they have undergone.

Stable inclinations (I) are obtainable for rocks of all sites except Site 473 , from which all specimens invariably show unstable directions, although their $J_{n}$ values are relatively high.
We split a sample from Hole 470A (470A-8-1, 104$108 \mathrm{~cm}$ ) into two specimens for a more detailed study. This sample showed a small crack around which intense oxidation was visible (yellowish brown in color). We extracted two minicores from this sample: one near this crack (categorized as "oxidized"; yellowish brown in 
Table 2. Hysteresis and thermomagnetic characteristics of Leg 63 igneous rocks.

\begin{tabular}{cccccccccccccc}
\hline $\begin{array}{c}\text { Sample } \\
\text { (interval in cm) }\end{array}$ & $M_{S}$ & $M_{r}$ & $M_{r} / M_{S}$ & $H_{c}$ & $H_{c r}$ & $H_{c r} / H_{c}$ & $\chi_{i}$ & $x_{p}$ & $\chi_{i} / \chi_{p}$ & $T_{c}$ & $\begin{array}{c}\text { Heating and Cooling } \\
\text { Cycle Descriptions }\end{array}$ \\
\hline
\end{tabular}

Hole 469

$\begin{array}{lrllrrrrrr}42-4,66-68 & 0.48 & 0.042 & 0.09 & 39 & 100 & 2.6 & 1.1 & 1.0 & 110 \\ & 0.66 & 0.038 & 0.06 & 31 & 106 & 3.4 & 1.2 & 0.9 & 133 \\ 42-5,76-78 & 0.49 & 0.046 & 0.09 & 38 & 84 & 2.2 & 1.2 & 1.0 & 120 \\ & 0.57 & 0.051 & 0.09 & 47 & 150 & 3.2 & 1.1 & 1.0 & 110 \\ 42-6,21-23 & 0.68 & 0.082 & 0.12 & 51 & 110 & 2.2 & 1.6 & 1.3 & 123 \\ & 0.93 & 0.069 & 0.07 & 39 & 125 & 3.2 & 1.8 & 1.4 & 129 \\ 45-2,114-116 & 1.08 & 0.28 & 0.26 & 106 & 147 & 1.4 & 2.6 & 0.9 & 289 \\ & 0.85 & 0.28 & 0.33 & \text { n.d. } & \text { n.d. } & \text { n.d. } & \text { n.d. } & 1.7 & \text { n.d. } \\ 46-2,23-25 & 0.57 & 0.15 & 0.26 & 120 & 187 & 1.6 & 1.3 & 1.0 & 130 \\ & 0.99 & 0.16 & 0.16 & 81 & 172 & 2.1 & 2.0 & 0.7 & 286\end{array}$

\begin{tabular}{|c|c|}
\hline 438 & h.c. irreversible \\
\hline 495 & c.c. heated to $500^{\circ} \mathrm{C}$ at $10^{\circ} \mathrm{C} / \mathrm{min}$. \\
\hline 404 & h.c. irreversible \\
\hline $\left.\begin{array}{l}497 \\
501\end{array}\right\}^{\mathrm{a}}$ & c.c. heated to $560^{\circ} \mathrm{C}$ at $5^{\circ} \mathrm{C} / \mathrm{min}$ \\
\hline 379 & h.c. irreversible \\
\hline 489 & c.c. heated to $490^{\circ} \mathrm{C}$ at $10^{\circ} \mathrm{C} / \mathrm{min}$. \\
\hline 309 & h.c. irreversible \\
\hline $\begin{array}{l}489,138 \\
317\end{array}$ & $\begin{array}{l}\text { c.c. heated to } 580^{\circ} \mathrm{C} \text { at } 10^{\circ} \mathrm{C} / \mathrm{min} \text {. } \\
\text { h.c. irreversible }\end{array}$ \\
\hline 516 & c.c. heated to $540^{\circ} \mathrm{C}$ at $20^{\circ} \mathrm{C} / \mathrm{mi}$ \\
\hline 331 & h.c. irreversible \\
\hline 483,139$)$ & c.c. heated to $600^{\circ} \mathrm{C}$ at $10^{\circ} \mathrm{C} / \mathrm{min}$. \\
\hline
\end{tabular}

Hole 470

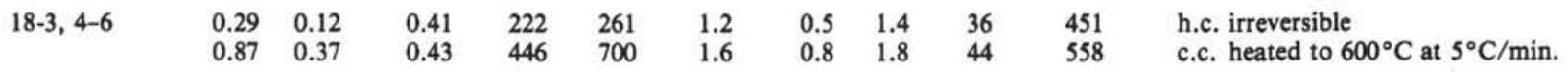

Hole 470A

$\begin{array}{lllllrlllll}\text { 7-3, 76-78 } & 0.20 & 0.10 & 0.50 & 371 & 548 & 1.5 & 0.3 & 1.3 & 23 & 457 \\ & 0.40 & 0.17 & 0.43 & 368 & 593 & 1.6 & 0.5 & 1.5 & 33 & 535 \\ \text { 8-1, 104-108; } & 0.15 & 0.049 & 0.33 & 555 & 1050 & 1.9 & 0.1 & 0.9 & 11 & 408 \\ \text { "fresh" } & 0.28 & 0.092 & 0.33 & 292 & 447 & 1.5 & 0.3 & 1.0 & 30 & 522 \\ \text { 8-1, 104-108; } & 0.13 & 0.051 & 0.39 & 465 & 880 & 1.9 & 0.1 & 0.9 & 11 & 382 \\ \text { "oxidized" } & 0.48 & 0.11 & 0.23 & 222 & 412 & 1.9 & 0.5 & 1.7 & 29 & 524 \\ \text { 9-4, 96-98 } & 0.11 & 0.059 & 0.54 & 458 & 630 & 1.4 & 0.1 & 1.2 & 8 & 369 \\ & 0.81 & 0.35 & 0.43 & 453 & 627 & 1.4 & 0.8 & 1.5 & 53 & 569\end{array}$

Site 471

\begin{tabular}{|c|c|c|c|c|c|c|c|c|c|c|}
\hline $79-1,118-120$ & $\overline{\text { (very }}$ & weak: & - & le) & - & - & - & - & - & - \\
\hline $84-1,40-42$ & 0.77 & 0.091 & 0.12 & 66 & 156 & 2.4 & 1.4 & 1.4 & 100 & 525 \\
\hline $85-1,18-20$ & 1.10 & 0.073 & 0.07 & 63 & 198 & 3.1 & 1.2 & 1.2 & 100 & 508 \\
\hline $88-3,82-84$ & $\begin{array}{l}0.31 \\
0.28\end{array}$ & 0.019 & 0.06 & 49 & 157 & 3.2 & 0.4 & 1.2 & 33 & 04 \\
\hline
\end{tabular}

Site 472

$\begin{array}{lllllllllll}\text { 14-1, 145-150; } & 0.12 & 0.065 & 0.54 & 318 & 395 & 1.2 & 0.2 & 1.0 & 20 & 379 \\ \text { "core" } & 0.83 & 0.39 & 0.47 & 592 & 758 & 1.3 & 0.7 & 1.1 & 64 & 570 \\ \text { 14-1, 145-150; } & 0.16 & 0.096 & 0.60 & 413 & 500 & 1.2 & 0.2 & 1.5 & 13 & 378 \\ \text { "margin" } & 0.91 & 0.42 & 0.46 & 598 & 750 & 1.3 & 0.7 & 1.3 & 54 & 574 \\ 16-1,45-51 & 0.12 & 0.073 & 0.61 & 420 & 547 & 1.3 & 0.2 & 1.2 & 17 & 287 \\ & 1.11 & 0.47 & 0.42 & 416 & 575 & 1.4 & 1.1 & 1.4 & 79 & 557 \\ 16-2,62-64 & 0.13 & 0.083 & 0.64 & 368 & 464 & 1.3 & 0.2 & 1.4 & 14 & 309 \\ & 1.11 & 0.44 & 0.40 & 366 & 520 & 1.4 & 1.2 & 1.5 & 80 & 580\end{array}$

Site 473

\begin{tabular}{|c|c|c|c|c|c|c|c|c|c|c|c|}
\hline \multirow{3}{*}{$\begin{array}{l}32-1,77-84 ; \\
\text { 'b' subsample }\end{array}$} & 0.82 & 0.14 & 0.17 & 57 & 129 & 2.3 & 2.5 & 1.5 & 167 & 183 & \multirow{8}{*}{$\begin{array}{l}\text { reversible } \\
\text { heated to } 270^{\circ} \mathrm{C} \text { at } 10^{\circ} \mathrm{C} / \mathrm{min} \text {. } \\
\text { reversible? } \\
\text { heated to } 600^{\circ} \mathrm{C} \text { at } 2.5^{\circ} \mathrm{C} / \mathrm{min} \text {. } \\
\text { reversible? } \\
\text { heated to } 600^{\circ} \mathrm{C} \text { at } 2.5^{\circ} \mathrm{C} / \mathrm{min} \text {. } \\
\text { reversible? } \\
\text { heated to } 600^{\circ} \mathrm{C} \text { at } 10^{\circ} \mathrm{C} / \mathrm{min} \text {. } \\
\text { reversible? } \\
\text { heated to } 600^{\circ} \mathrm{C} \text { at } 2.5^{\circ} \mathrm{C} / \mathrm{min} \text {. } \\
\text { reversible? } \\
\text { heated to } 550^{\circ} \mathrm{C} \text { at } 5^{\circ} \mathrm{C} / \mathrm{min} \text {. }\end{array}$} \\
\hline & 0.82 & 0.15 & 0.18 & 59 & 132 & 2.2 & 2.5 & 1.5 & 167 & & \\
\hline & 0.49 & 0.064 & 0.13 & 34 & 88 & 2.6 & 1.9 & 0.9 & 211 & $189^{\mathrm{a}}$ & \\
\hline $32-3,76-84$ & & & & & & & & & & 163 & \\
\hline $\begin{array}{l}33-1,66-74 ; \\
\text { 'a' subsample }\end{array}$ & & & & & & & & & & 159 & \\
\hline $34-3,10-17$ & 0.98 & 0.16 & 0.16 & 42 & 101 & 2.4 & 3.8 & 1.8 & 211 & 135 & \\
\hline $34-3,33-35$ & 1.03 & 0.36 & 0.35 & 121 & 162 & 1.3 & 3.0 & 2.1 & 143 & 217 & \\
\hline & 0.81 & 0.27 & 0.33 & 128 & 166 & 1.3 & 2.1 & 1.7 & 124 & & \\
\hline
\end{tabular}

Note: $M_{S}$ is saturation magnetization in emu g ${ }^{-1} ; M_{r}$ is saturation remanent magnetization in emu g ${ }^{-1} ; H_{C}$ is coercive force in oe; $H_{C r}$ is remanent coercive force in oe; $\chi_{i}$ is initial susceptibility $\left(M_{r} / H_{C}\right)$ in $10^{-3} \mathrm{emu} \mathrm{g}-1 \mathrm{oe}^{-1} ; \chi_{p}$ is high-field susceptibility (mean slope of hysteresis "saturation" curve) in $10^{-5} \mathrm{emu} \mathrm{g}^{-1} \mathrm{oe}^{-1} ; T_{c}$ is Curie temperature in ${ }^{\circ} \mathrm{C}$; h.c. is heating cycle; c.c. is cooling cycle; n.d. $=$ not determined. The first row of hysteresis data is on an unheated sample; the second row of data corresponds to that on the sample heated for obtaining thermomagnetic curve. For Sample 473-32-1, 77-84 cm, the first row contains data on the unheated sample, whereas two sets of "heated" data are obtained: one for the sample heated to $260^{\circ} \mathrm{C}$ and the other for the sample heated to $600^{\circ} \mathrm{C}$.

a Duplicate measurement; indicates reproducibility.

b "Concave" type cooling curve is obtained; when reheated, the "concave"-type curve persists. 

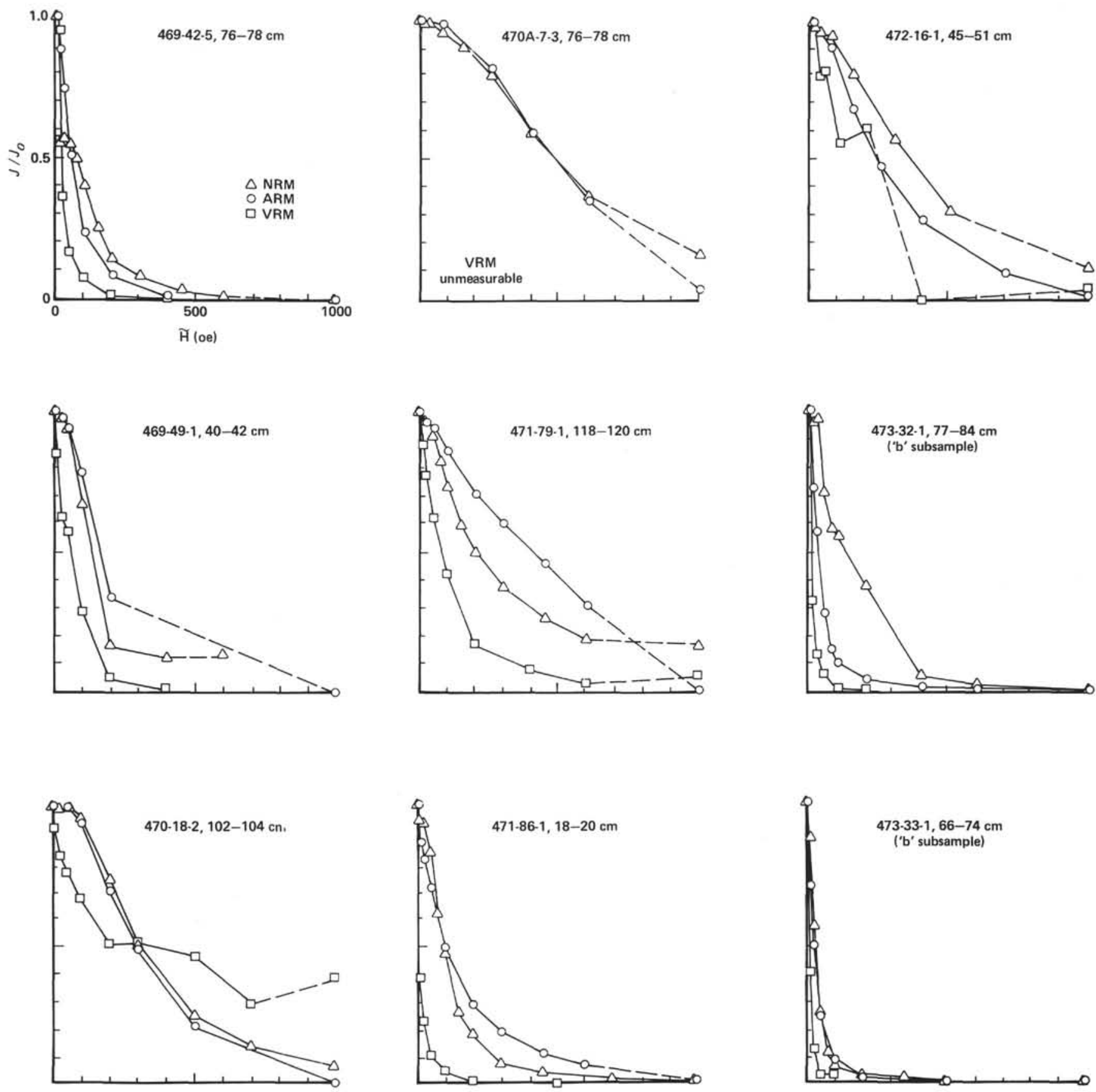

Figure 1. Step-wise AF demagnetization curves of NRM, ARM, and VRM for selected samples. ( $J_{o}$ refers to initial intensity of NRM, ARM, or VRM, i.e., prior to AF demagnetization.)

color) and the other further away from it (identified as "fresh"; grayish in color). Our aim in this case was to study the effects of oxidation on magnetic properties.

Our results show that the $J_{n}$ of NRM is considerably lower for the "oxidized" specimen in comparison to its "fresh" counterpart. The same is the case with the $M D F_{n}$. The sample itself was not oriented, but the minicores could be oriented relative to each other (so that their inclinations were comparable). The "oxidized" specimen showed somewhat more variability in its inclination than did the "fresh" one.

\section{Anhysteritic Remanent Magnetization: $J_{a}, M D F_{a}$}

We conducted ARM acquisition experiments on all the samples. For this purpose we applied a 1000 -oe alternating field $(\widetilde{\mathrm{H}})$ in the presence of a steady 1-oe direct field $(\overrightarrow{\mathrm{H}})$ and then reduced the AF (alternating field) slowly to zero oe. We normalized the measured ARM intensity to 0.5 oe by dividing the measured value by 2 (so that the $J_{n}$ and $J_{a}$ were directly comparable). We also tested the stability of the ARM by AF demagnetization. The normalized ARM intensities $\left(J_{a}\right)$ and their me- 
Table 3. Average magnetization characteristics of Leg 63 sites.

\begin{tabular}{|c|c|c|c|c|c|c|c|c|c|c|}
\hline \multirow{3}{*}{$\begin{array}{c}\text { Magnetic } \\
\text { property } \\
(n)^{\mathrm{a}}\end{array}$} & \multicolumn{2}{|c|}{ Site 469} & \multirow{3}{*}{$\begin{array}{c}\text { Hole } 470 \\
\text { Basalt } \\
\text { (2) }\end{array}$} & \multirow{3}{*}{$\begin{array}{c}\text { Hole } 470 \mathrm{~A} \\
\text { Basalt } \\
(6)\end{array}$} & \multicolumn{2}{|c|}{ Site 471} & \multirow{3}{*}{$\begin{array}{c}\text { Site } 472 \\
\text { Basalt } \\
\text { (4) }\end{array}$} & \multirow{3}{*}{$\begin{array}{c}\text { Site } 473 \\
\text { Diabase } \\
(5)\end{array}$} & \multicolumn{2}{|c|}{ Leg 63} \\
\hline & Diabase & Basalt & & & Altered Diabase & Altered Diabase & & & Diabase & Basalt \\
\hline & (5) & (4) & & & (4) & (3) & & & (14) & (16) \\
\hline$J_{n}, 10^{-3} \mathrm{emu} \mathrm{cm}^{-3}$ & $0.53 \pm 0.19$ & $1.8 \pm 0.9$ & $15 \pm 13$ & $7.9 \pm 4.2$ & $0.37 \pm 0.44$ & $0.48 \pm 0.47$ & $2.7 \pm 0.9$ & $4.0 \pm 1.5$ & $1.7 \pm 2.0$ & $6.0 \pm 6.2$ \\
\hline$J_{a}, 10^{-3} \mathrm{emu} \mathrm{cm}^{-3}$ & $1.45 \pm 0.22$ & $5.3 \pm 1.9$ & $4.8 \pm 2.1$ & $1.6 \pm 0.6$ & $0.9 \pm 0.9$ & $1.1 \pm 0.9$ & $2.2 \pm 0.6$ & $8.5 \pm 1.2$ & $3.8 \pm 3.7$ & $3.1 \pm 2.0$ \\
\hline$J_{\text {vex }}, 10^{-3} \mathrm{emu} \mathrm{cm}^{-3}$ & $0.28 \pm 0.23$ & $0.67 \pm 0.29$ & $0.32 \pm 0.25$ & - & $0.19 \pm 0.18$ & $0.25 \pm 0.17$ & - & $2.2 \pm 0.4$ & $0.9 \pm 1.0$ & $\begin{aligned} 0.4 & \pm 0.3 \\
(\mathrm{n} & =8)\end{aligned}$ \\
\hline$J_{a} / J_{n}$ & $3.1 \pm 1.4$ & $3.7 \pm 2.1$ & $0.45 \pm 0.21$ & $0.22 \pm 0.15$ & $3.6 \pm 1.8$ & $3.5 \pm 2.2$ & $0.88 \pm 0.25$ & $2.3 \pm 0.6$ & $2.9 \pm 1.3$ & $1.3 \pm 1.7$ \\
\hline$J_{\text {vex }} / J_{n}$ & $0.8 \pm 0.3$ & $0.38 \pm 0.05$ & $0.02 \pm 0.01$ & - & $0.8 \pm 0.6$ & $0.9 \pm 0.6$ & - & $0.6 \pm 0.2$ & $0.8 \pm 0.3$ & $\begin{aligned} 0.2 & \pm 0.2 \\
(\mathrm{n} & =8)\end{aligned}$ \\
\hline$M D F_{n}$ & $64 \pm 21$ & $13 i \pm 15$ & $303 \pm 7$ & $730 \pm 196$ & $133 \pm 53$ & $110 \pm 34$ & $575 \pm 152$ & $\begin{array}{c}59 \pm 39 \\
(42 \pm 5 \\
\mathrm{n}=4)\end{array}$ & $82 \pm 49$ & $488 \pm 285$ \\
\hline$M D F_{a}$ & $51 \pm 12$ & $145 \pm 14$ & $277 \pm 29$ & $561 \pm 101$ & $175 \pm 153$ & $98 \pm 6$ & $348 \pm 80$ & $24 \pm 4$ & $77 \pm 99$ & $368 \pm 185$ \\
\hline$M D F_{v}$ & $16 \pm 6$ & $71 \pm 28$ & $235 \pm 177$ & - & $38 \pm 31$ & $24 \pm 17$ & - & $8 \pm 1$ & $20 \pm 20$ & $\begin{aligned} 144 & \pm 117 \\
(\mathrm{n} & =7)\end{aligned}$ \\
\hline$M D F_{a} / M D F_{n}$ & $0.8 \pm 0.2$ & $1.1 \pm 0.2$ & $0.95 \pm 0.07$ & $0.78 \pm 0.12$ & $1.2 \pm 0.6$ & $0.9 \pm 0.3$ & $0.60 \pm 0.08$ & $0.5 \pm 0.2$ & $0.8 \pm 0.4$ & $0.8 \pm 0.2$ \\
\hline$M D F_{v} / M D F_{n}$ & $0.3 \pm 0.1$ & $0.6 \pm 0.3$ & $0.8 \pm 0.6$ & - & $0.25 \pm 0.1$ & $0.2 \pm 0.1$ & - & $0.2 \pm 0.1$ & $0.2 \pm 0.1$ & $\begin{array}{c}0.6 \pm 0.3 \\
(\mathrm{n}=10)\end{array}$ \\
\hline$x, 10^{-3} \mathrm{emu} \mathrm{cm}^{-3} \mathrm{oe}^{-1}$ & $19 \pm 3$ & $29 \pm 8$ & $6 \pm$ & $2.3 \pm 1.1$ & $18 \pm 15$ & $24 \pm 13$ & $1.9 \pm 0.4$ & $45 \pm 12$ & $28 \pm 17$ & $9 \pm 12$ \\
\hline$Q_{n}^{\prime}\left(=J_{n} / \chi\right)$ & $0.029 \pm 0.011$ & $0.066 \pm 0.035$ & $2.7 \pm 2.6$ & $3.6 \pm 1.7$ & $0.019 \pm 0.014$ & $0.017 \pm 0.016$ & $1.5 \pm 0.6$ & $0.094 \pm 0.040$ & $0.049 \pm 0.042$ & $2.1 \pm 1.9$ \\
\hline$Q_{n}\left(=J_{n} / 0.45 x\right)$ & $0.063 \pm 0.026$ & $0.15 \pm 0.08$ & $5.9 \pm 5.7$ & $8.0 \pm 3.8$ & $0.042 \pm 0.030$ & $0.039 \pm 0.037$ & $3.3 \pm 1.4$ & $0.21 \pm 0.09$ & $0.11 \pm 0.10$ & $4.6 \pm 4.2$ \\
\hline
\end{tabular}

$a_{n}=$ number of samples from each site.

dian destructive fields $\left(M D F_{a}\right)$ as well as $J_{a} / J_{n}$ and $M D F_{a} / M D F_{n}$ ratios are presented in Table 1 . Some demagnetization curves are included in Figure 1.

We selected samples from each site to study the dependence of ARM on direct as well as alternating fields. Figures 2 and 3 synthesize these results. Figure 2 shows a linear dependence of the ARM on direct fields of up to 1.5 oe applied in the presence of 1000 -oe peak $\widetilde{\mathrm{H}}$. This is an expected behavior of the ARM and shows that the 1-oe direct field used in all ARM acquisition experiments is adequate to conduct these acquisition experiments. Figure 3 presents the ARM acquired in different alternating-field values of up to 1000 oe in the presence of a constant $\overrightarrow{\mathrm{H}}$ of 1 oe.

The results shown in Figure 3 are interesting. They in dicate that the ARMs acquired by the samples from Sites 469,471 and 473 alone are saturated well before reaching the 1000 -oe field. This means that the 1000 -oe $\widetilde{\mathrm{H}}$ is large enough for the ARM acquisition experiments for these samples. On the other hand, the ARMs acquired by the samples from Holes $470,470 \mathrm{~A}$, and 472 do not reach saturation even at 1000 oe $\widetilde{\mathrm{H}}$, implying that for the study of these samples we need still higher $\widetilde{\mathrm{H}}$ beyond the range of most commercial AF demagnetizers. Thus the $J_{a}$ of these samples in the 1000-oe field and the $J_{a} / J_{n}$ ratio can be compared only roughly with those of the other samples. Levi and Merrill (1976) have studied one sample having needle-shaped magnetite particles. This sample possessed unsaturated ARM for an alternating field up to 2000 oe.

The ARM and thermoremanent magnetization (TRM) acquired by magnetite grains possess similar AF demagnetization spectra (Dunlop and West, 1969; Levi, 1973; Levi and Merrill, 1976). Further, both $J_{a}$ and $J_{t}$ (intensity of TRM) increase with the decrease in grain size (Parry, 1965; Gillingham and Stacey, 1971). Levi and Merrill (1976), however, have observed an increase in the $J_{a} / J_{t}$ ratio with decreasing grain size. Similar properties have also been observed in titanomagnetite samples (Kono, 1978). On the basis of these observations, Hamano et al. (1979) have used the ARM and its relation to NRM in oceanic basalts to make conclusions

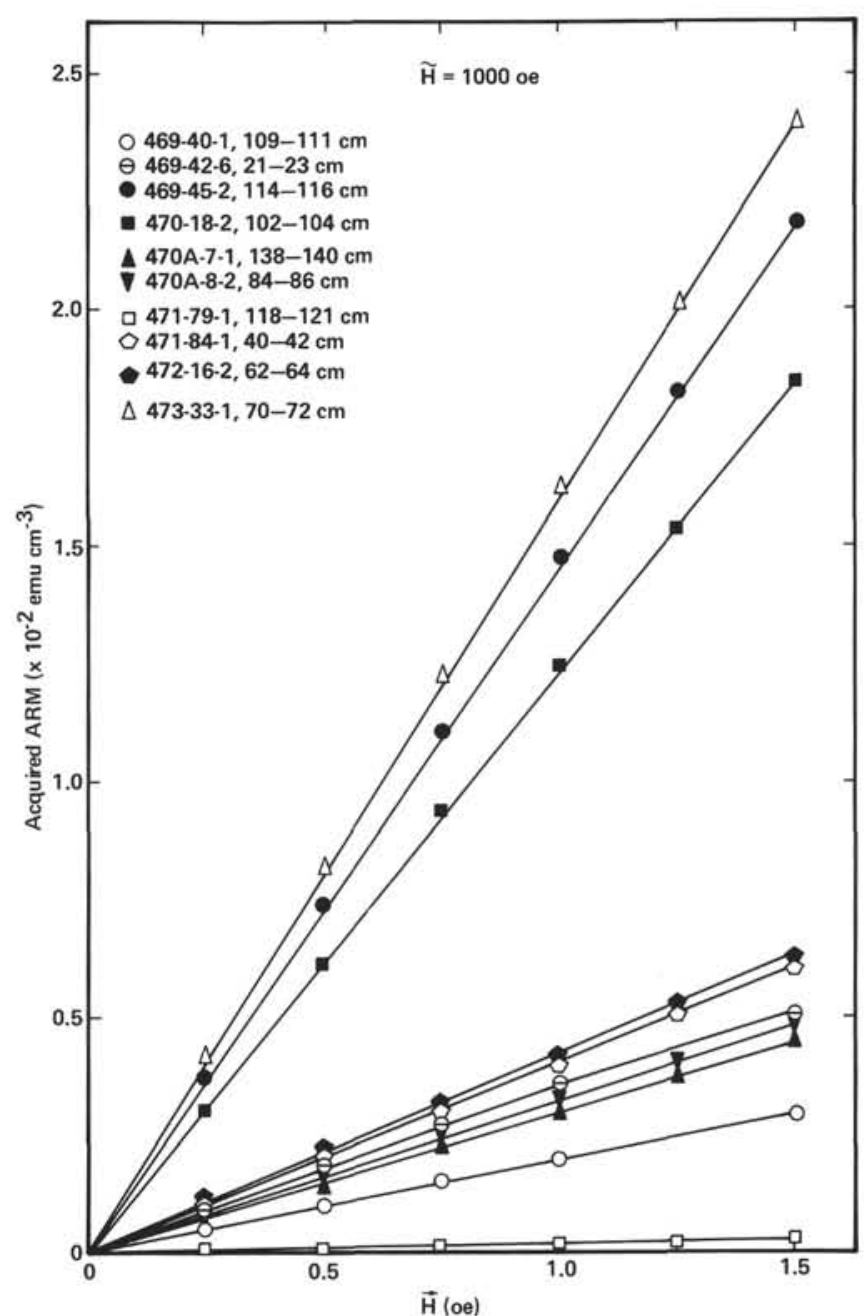

Figure 2. ARM acquired as a function of applied direct field. (Note the ARM intensities are actual values [not normalized]. Open symbols are used for diabases, and filled symbols are for basalts.)

about the NRM in titanomagnetites contained in those rocks.

In the present work, $J_{a}$ ranges from 0.114 to $9.55 \times$ $10^{-3} \mathrm{emu}^{-3}$. Unlike Hamano et al. (1979), who 


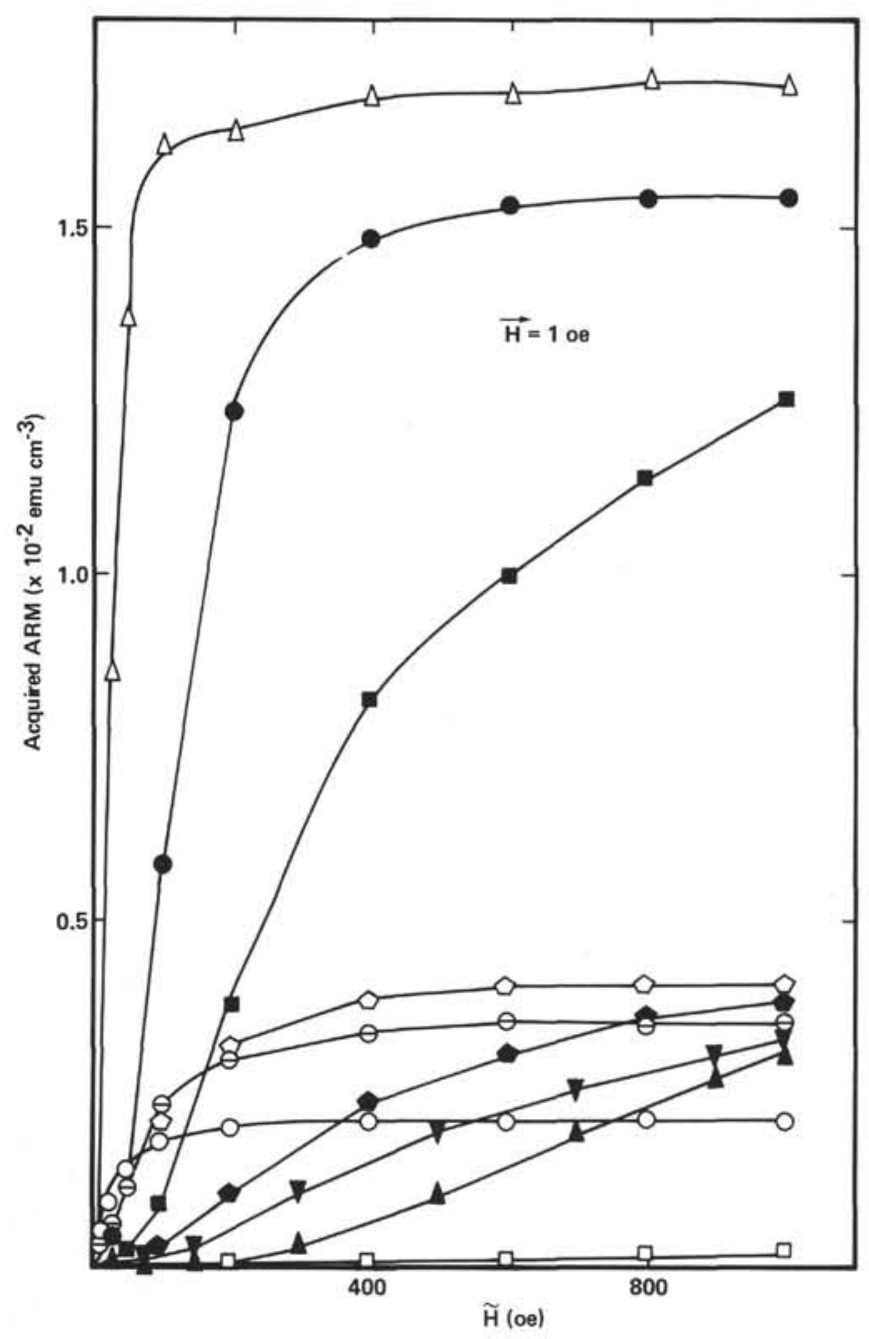

Figure 3. ARM acquired as a function of applied alternating field. (Note the ARM intensities are actually measured values and are not normalized to 0.5 oe $[\overrightarrow{\mathrm{H}}]$. For explanation of symbols, see the legend in Fig. 2.)

observed variation in $J_{a}$ by a factor of 4 only, the range of variation of $J_{a}$ in Leg 63 igneous rocks is almost 2 orders of magnitude. This variation in $J_{a}$ is, however, less than that observed in corresponding $J_{n}$, which varies by about 3 orders of magnitude.

As stated earlier, we have obtained stepwise AF demagnetization curves of the NRM and ARM of all the samples. Figure 1 shows some typical curves. Figure 4 and Table 1 give the relationship between $M D F_{a}$ and $M D F_{n}$. We see that although the two $M D F$ s are similar, $M D F_{n}$ is generally larger than or equal to $M D F_{a}$. Only six samples show the opposite relationship; notable is the case of Sample 471-79-1, 118-120 cm, an altered diabase, which shows a typically high ratio of $M D F_{a}$ I $M D F_{n}$. Levi and Merrill (1976) have observed a significantly high $M D F_{a}$ (as compared to its $M D F_{n}$ ) for one sample having needle-shaped magnetite grains, but this sample also possessed unsaturated ARM for alternating fields up to 2000 oe.

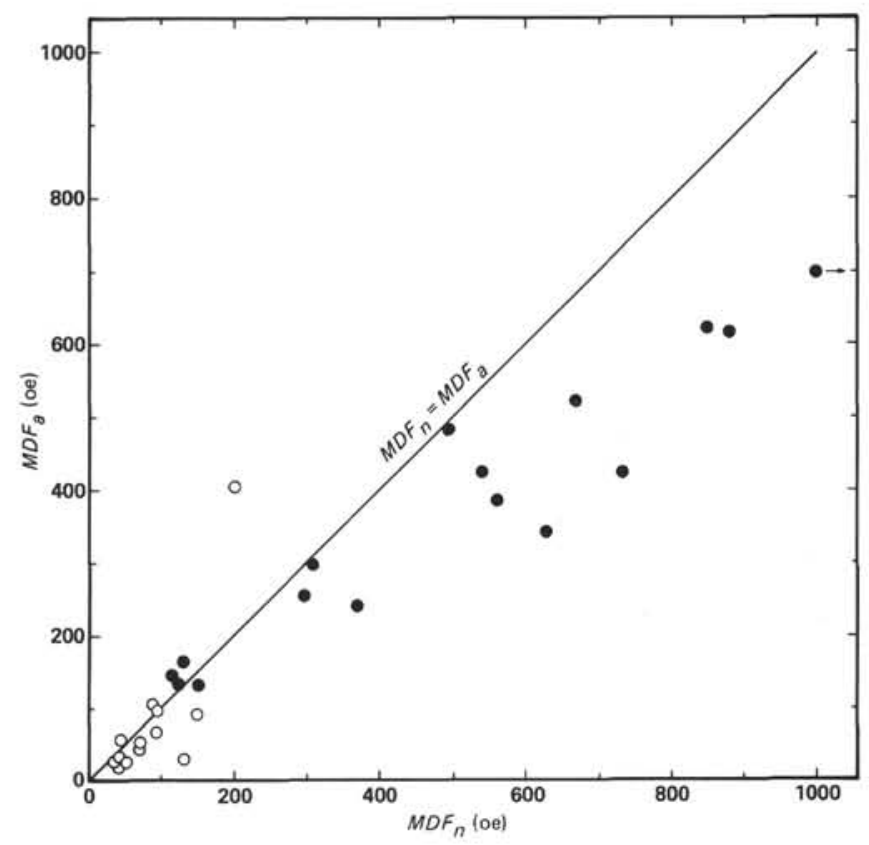

Figure 4. Comparison of median destructive fields of NRM $\left(M D F_{n}\right)$ and ARM $\left(M D F_{a}\right)$. (Open circles signify diabases, and filled circles basalts.)

The basalts from Holes 470 and 470A show considerably low $J_{a} / J_{n}$ ratios. However, the ARM acquired by them in 1000 oe $\widetilde{\mathrm{H}}$ is still below saturation. Their ARM and NRM demagnetization curves are also very similar. These combined facts suggest that a large part of the NRM in these basalts may be the original TRM component. On the other hand, the basalts from Site 469 as well as all the diabases show considerably higher $J_{a} / J_{n}$ ratios (always $>1$ ) reflecting perhaps the effects of grain-size variation of the corresponding magnetic minerals, which may have resulted from secondary alteration.

Viscous Remanent Magnetization: $J_{v}, J_{v e x}, M D F_{v}$

Prior to the VRM experiments, we demagnetized all but five specimens in a 1000 -oe peak alternating field in order to remove the bulk of the NRM. We used five specimens (namely, Samples 469-41-3, 62-64 cm; 46946-2, 23-25 cm; 470A-7-1, 138-140 cm; 471-88-3, 82-84 $\mathrm{cm}$; and 473-33-1, 66-74 cm, 'a' specimen) to study first the acquisition of VRM superposed on NRM and then the acquisition of VRM on the demagnetized specimens. This process permitted us to compare the rates of VRM acquisition on NRM to those on demagnetized states. Figure 5 gives the corresponding VRM growth curves.

VRM growth curves typically consist of two or sometimes three distinct segments. Such growth curves consisting of distinct segments have been obtained earlier for many other DSDP basalts (e.g., Lowrie, 1974; Kent and Lowrie, 1977). The growth of the VRM proceeds logarithmically with time but at higher rates in later segments. We attempted least-square fittings of the type $J_{v}=a+b \log t$ (straight line of VRM intensity 

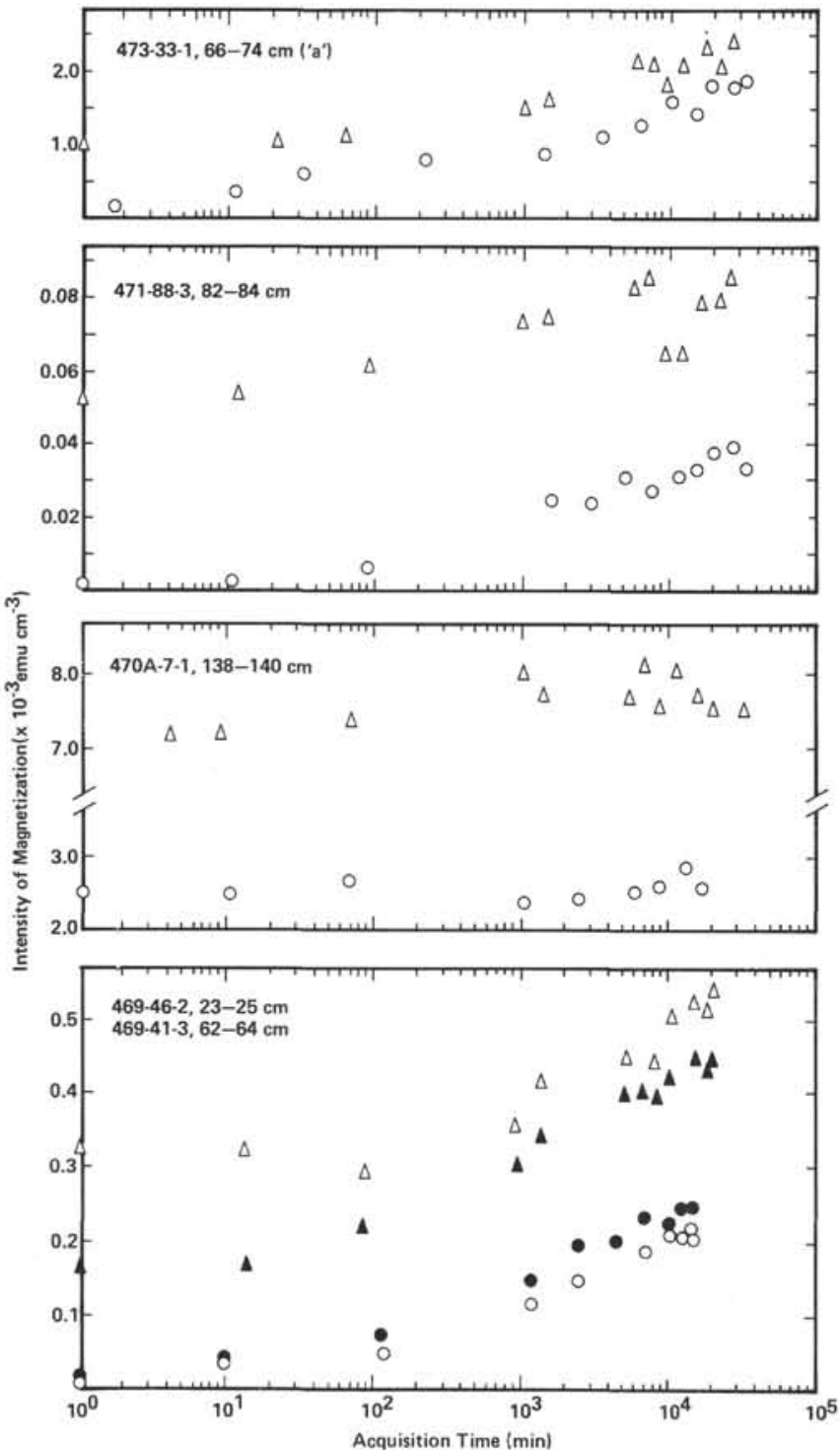

Figure 5. Comparison of VRM acquisition data for five specimens, acquired on initial NRM and initially AF-demagnetized states. (The horizontal axis of the plot is acquisition time in min [logarithmic scale], whereas the vertical axis is magnetization intensity in $10^{-3}$ emu $\mathrm{cm}^{-3} \cdot \Delta$ stands for VRM $+Z_{\text {NRM }}$ [on NRM state] and $\bigcirc$ for VRM $+Z_{n 1000 \text { oe }}$ [on demagnetized state]. Filled symbols are for Sample $469-41-3,62-64 \mathrm{~cm}$.)

versus logarithm of time) for each segment of VRM growth curves. The extrapolated values $\left(J_{\text {vex }}\right)$ for $10^{5}$ min are given in Table 1. For comparison, the extrapolated values of VRM on NRM $\left(J_{\text {vnex }}\right)$ for the five specimens studied are also included in this table.

For some oceanic basalts, Lowrie and Kent (1975) have observed that the VRM acquired superposed on NRM can develop almost twice as rapidly compared to VRM acquired from the demagnetized state. Our results are not consistent with their observation. Two of the five specimens (both from Site 469) show that the VRM acquired from the NRM is slightly higher than the VRM acquired on demagnetized states (but not twice as high). On the other hand, two specimens (from Sites 471 and
473) show the opposite tendency, i.e., their VRM on NRM is lower than the VRM on demagnetized states. The sample from Hole 470A, however, does not acquire a measurable VRM component in either of the two states.

Our results indicate such low VRM components (almost unmeasurable during VRM experiments) for basalts from Holes $470,470 \mathrm{~A}$, and 472 that VRM cannot be considered a serious problem at these sites. The rocks from these holes have stable magnetizations characterized by very high $M D F_{n}$ values. Figure 6 gives a plot of $J_{\text {vex }} / J_{n}$ versus $M D F_{n}$ on a log-log scale. In this figure, these basalts fall very close to the $M D F_{n}$ axis, whereas the samples from Sites 469,471 , and 473 show much greater ability to acquire VRM. In some samples, the VRM component acquired in $10^{5} \mathrm{~min}$ is as high or even higher than the measured NRM intensity $\left(J_{\text {vex }} / J_{n}\right.$ $\geq 1$ ). The VRM/ARM intensity ratio seems to be inversely related to the median destructive field of the NRM. Thus although there is considerable spread of the data around the "best-fit" straight line (Fig. 6), the relationship can be expressed approximately as $\left(J_{v e x} / J_{n}\right)$ $\cong 5500\left(M D F_{n}\right)^{-2.1}$.

We have AF demagnetized the VRM acquired during laboratory experiments by all the samples in order to test their VRM stability and to compare it with the corresponding NRM stability. The median destructive fields $\left(M D F_{v}\right)$ are listed in Table 1 along with the other $M D F$ s $\left(M D F_{n}\right.$ and $\left.M D F_{a}\right)$. The $M D F_{v}$ is almost invariably lower than the corresponding $M D F_{n}$. One exception is a basalt from Site 470 (Sample 18-2, 102-104

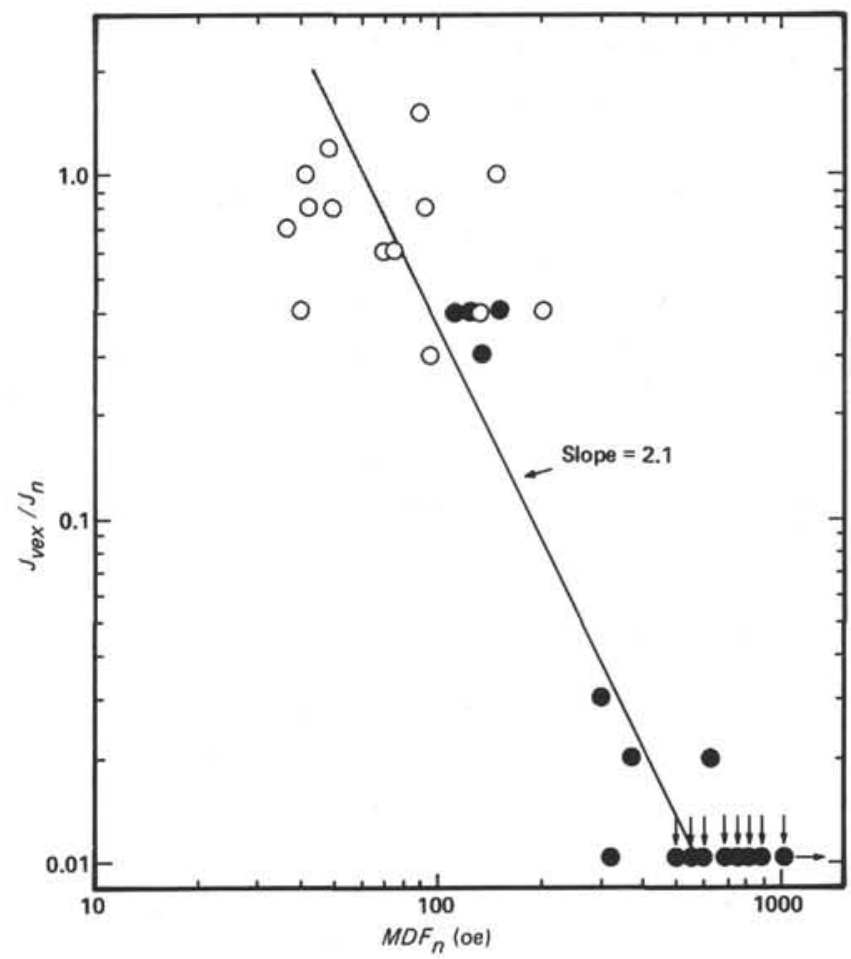

Figure 6. Variation of the ratio of extrapolated VRM intensity $\left(10^{5}\right.$ min) to NRM intensity as a function of the median destructive field for NRM $\left(M D F_{n}\right)$. 
$\mathrm{cm}$ ) for which $M D F_{v} / M D F_{n}=1.2$. This exception does not, however, have any serious consequence on its NRM because the intensity of VRM acquired by this sample is very low $\left(J_{v e x} / J_{n} \approx 0.01\right)$.

Thus we have demonstrated that although all the diabases and some basalts studied here can acquire significant VRM components, their $M D F_{v}$ are considerably lower than the corresponding $M D F_{n}$ (of the NRM), yet some of them (particularly the diabases of Site 473) do not give stable inclinations even after stepwise AF cleaning. The reason for this phenomenon is not clear at the present time.

\section{Saturation Magnetization: $\boldsymbol{M}_{\boldsymbol{s}}$}

We measured hysteresis properties of 20 samples. For most of them we also measured the hysteresis properties after the samples were heated (in a vacuum of $10^{-6}$ torr) in order to obtain thermomagnetic curves. A magnetic field of about 14.7 koe was used to acquire saturation.

The observed saturation magnetizations for the unheated samples range from 0.11 to $1.1 \mathrm{emu} \mathrm{g}^{-1}$, with an arithmetic mean of $0.49 \pm 0.37$ ( 20 samples). These values are somewhat lower than those observed at several DSDP sites (Grommé and. Mankinen, 1976; AdeHall et al., 1976; Hamano et al., 1979; Day et al., 1979) but are not too different from some other sites (Petersen, 1978; Johnson, 1978; Honnorez et al., 1978; Petersen et al., 1979). Figure 7 presents histograms of saturation magnetization $\left(M_{s}\right)$, saturation remanent magnetization $\left(M_{r}\right)$, and the $M_{r} / M_{s}$ ratio.

Consistent with the observation of Day et al. (1979), our results show that low-coercity samples have higher $M_{s}$ values (Fig. 8). Further, in accordance with Johnson (1978), the samples with low $M D F_{n}$ have higher $M_{s}$ values (Fig. 9).

\section{Saturation Remanent Magnetization: $M_{r}$ and $M_{r} / M_{s}$ Ratio}

Histograms of these parameters are given in Figure 7. $M_{r}$ varies from 0.019 to $0.36 \mathrm{emu}^{-1}$, with an arithmetic mean of $0.11 \pm 0.08 \mathrm{emu} \mathrm{g}^{-1}$, and shows a greater variation than $M_{s}$. This is consistent with the fact that $M_{r}$ is dependent on more variables than is $M_{s}$. $M_{r}$ depends on grain size and shape as well as on composition and concentration of magnetic minerals, whereas $M_{s}$ depends only on composition and concentration (Day et al., 1979).

The $M_{r} / M_{s}$ ratio has been used to give a good indication of the domain state of the magnetic minerals. Dunlop (1972) has shown that the ratio increases from 0.113 to 0.289 as the grain diameter decreases from 0.22 $\mu \mathrm{m}$ to $0.037 \mu \mathrm{m}$ for pure magnetite grains. Day et al. (1977) have studied synthetic titanomagnetites composed of $0.4 \mathrm{Fe}_{3} \mathrm{O}_{4}$ to $0.6 \mathrm{Fe}_{2} \mathrm{TiO}_{4}$ and found that $M_{r} /$ $M_{s}$ increases from about 0.05 to 0.47 as the grain size decreases from $140 \mu \mathrm{m}$ to $0.8 \mu \mathrm{m}$.

Values of $M_{r} / M_{s}$ around 0.5 or more are expected for single-domain (SD) grains whereas multidomain (MD) grains should have values below about 0.1 . Pseudo-
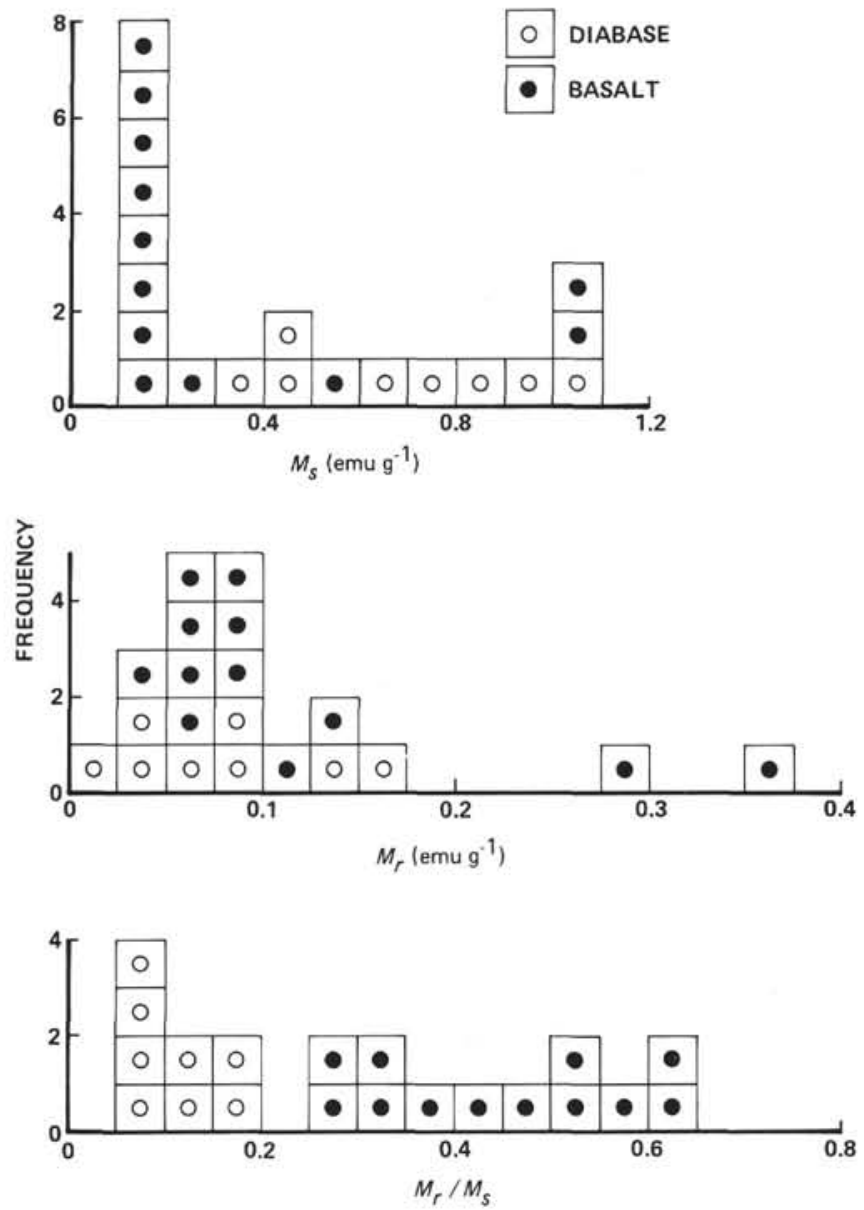

Figure 7. Histograms of saturation magnetization $\left(M_{s}\right)$, saturation remanent magnetization $\left(M_{r}\right)$, and the $M_{r} / M_{s}$ ratio.

single-domain (PSD) grains have values between 0.1 and 0.5 . Thus the diabases of Leg 63 contain mostly MD grains, and the basalts have SD and PSD grains. We note that the diabases and basalts are distinguishable on the $M_{r} / M_{s}$ histogram (Fig. 7). Hamano et al. (1979) have made a similar observation for massive flows and pillow basalts. We further note that the diabases and basalts are clearly distinguishable on a plot of $M_{r} / M_{s}$ against $M_{s}$ (Fig. 10).

Coercive Force $\left(H_{c}\right)$, Remanent Coercive Force $\left(H_{c r}\right)$, and Initial and High-Field Susceptibilities $\left(\chi_{i}\right.$ and $\left.\chi_{p}\right)$

Figure 11 gives histograms of $H_{c}, H_{c r}$, and $H_{c r} / H_{c}$. We note that the diabases and basalts are also distinguishable on these histograms. Perhaps more interesting is Figure 12, which is a plot of $M_{r} / M_{s}$ versus $H_{c r} / H_{c}$. The diabases and basalts form distinct fields on this diagram.

The initial and high-field susceptibilities $\chi_{i}$ and $\chi_{p}$ are also included in Table 2. Basalts from Holes 470, 470A, and 472 show somewhat lower $\chi_{i} / \chi_{p}$ ratios than do the basalts and diabases from the other sites (namely, Sites 469,471 , and 473), suggesting the presence of more paramagnetic iron in the silicate minerals. 


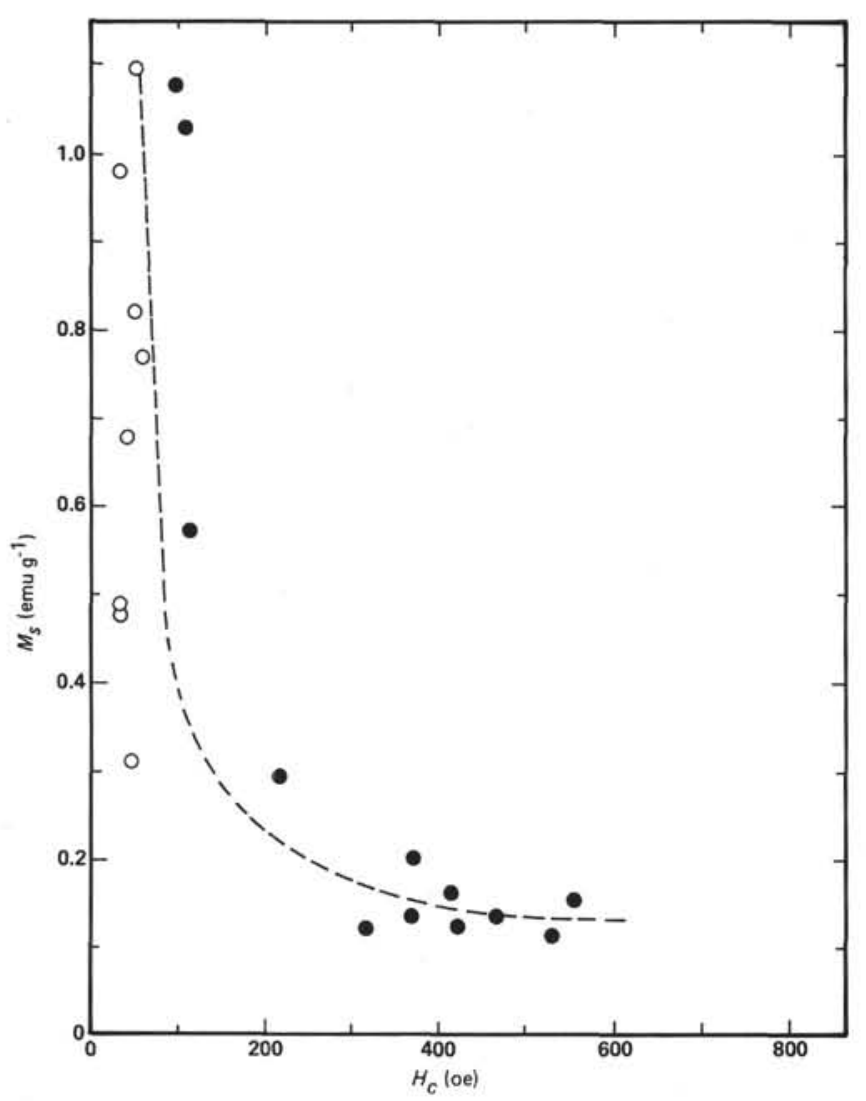

Figure 8. A plot of saturation magnetization $\left(M_{s}\right)$ against coercive force $\left(H_{c}\right)$. (Filled symbols are basalt samples, open symbols are diabase.)

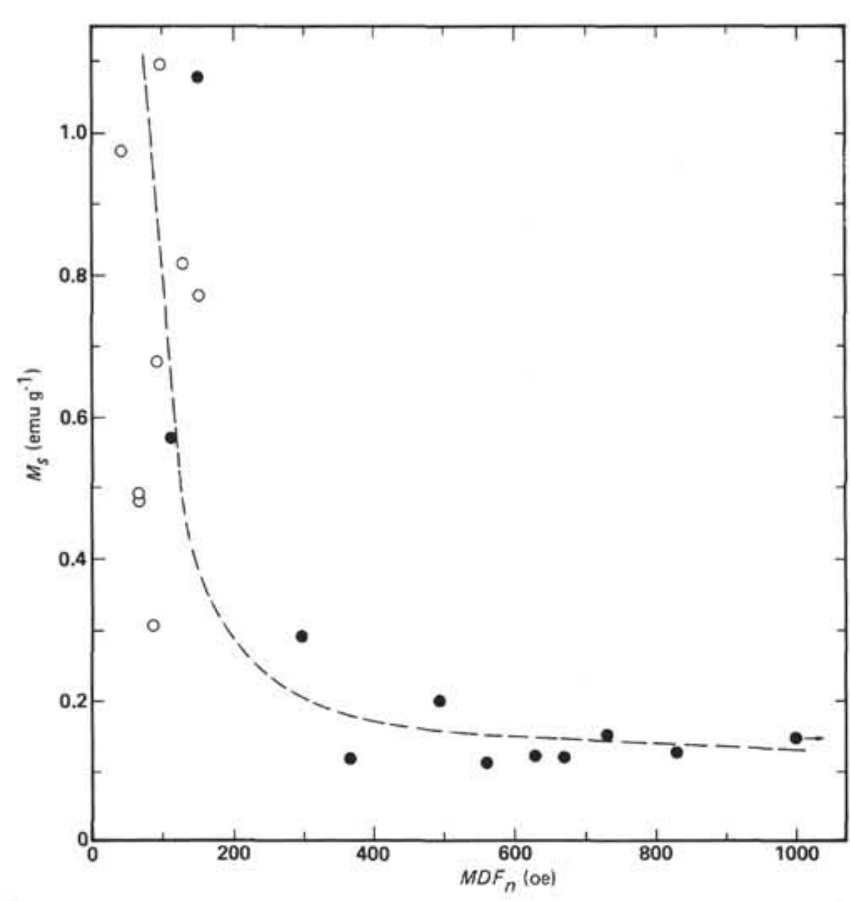

Figure 9. A plot of saturation magnetization $\left(M_{s}\right)$ against median destructive field for NRM $\left(M D F_{n}\right)$. (Filled symbols indicate basalt samples; open symbols indicate diabase.)

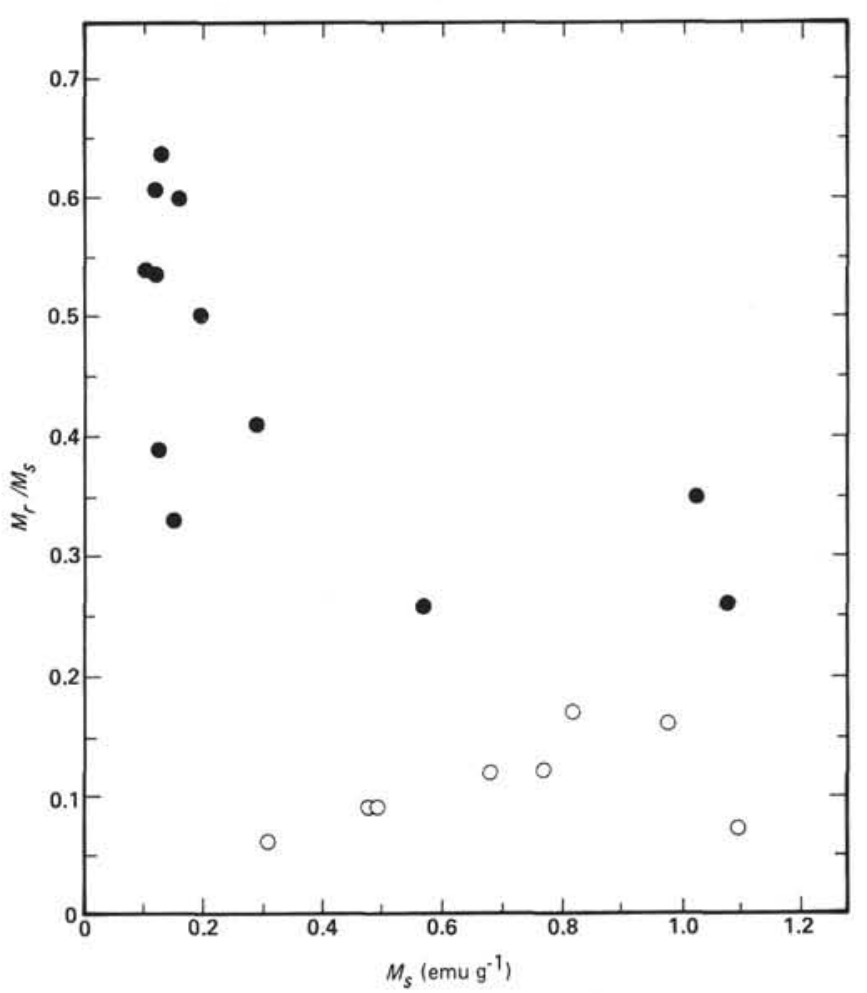

Figure 10. Variation of the ratio of saturation remanent magnetization to saturation magnetization as a function of the saturation magnetization. (Open symbols indicate diabases and closed symbols basalts; note the distinct fields for diabases and basalts.)

\section{Weak-Field Susceptibility: $\chi$}

The magnetic susceptibility $\chi$ of Leg 63 samples ranges from 1.5 to $54 \times 10^{-3} \mathrm{emu} \mathrm{cm}^{-3} \mathrm{oe}^{-1}$. Many samples from Sites 469,471 , and 473 show rather high susceptibility values, compared to most oceanic basalts and massive flows (e.g., Lowrie, 1974; Lowrie and Israfil, 1974; Lowrie and Hayes, 1975; Brecher et al., 1977; Petersen et al., 1978, 1979; Hamano et al., 1979).

The modified Koenigsberger ratio $Q_{n}^{\prime}(=\mathrm{NRM} / \chi)$ varies from 0.005 to 6.7 (Fig. 13 and Table 1). Similarly, the Koenigsberger ratio $Q_{n}(=\mathrm{NRM} / 0.45 \chi)$ ranges from 0.012 to 14.8 (Table 1 ). Table 2 gives the site mean ratios. We see that the site mean Koenigsberger ratios are generally less than the average Koenigsberger ratio (7.92) reported for a large number of DSDP basalts (Lowrie, 1974). This is perhaps because of the high susceptibilities observed in most diabases and some basalts. Although the remanence is the dominant magnetization component in Holes 470, 470A, and 472, induced magnetization components become dominant at Sites 469,471 , and 473 . The $Q_{n}$ ratios also suggest (Brecher et al., 1977; Petersen et al., 1979) that the remanence of the basalts from Holes $470,470 \mathrm{~A}$, and 472 is the result of fine-grain carriers $(Q>1$; single or pseudo-single domain grains), whereas coarse-grain carriers $(Q \ll 1$; multi-domain grains) are responsible at the other three sites.

Hamano et al. (1979) have observed an inverse correlation between susceptibility and NRM intensity. Our 

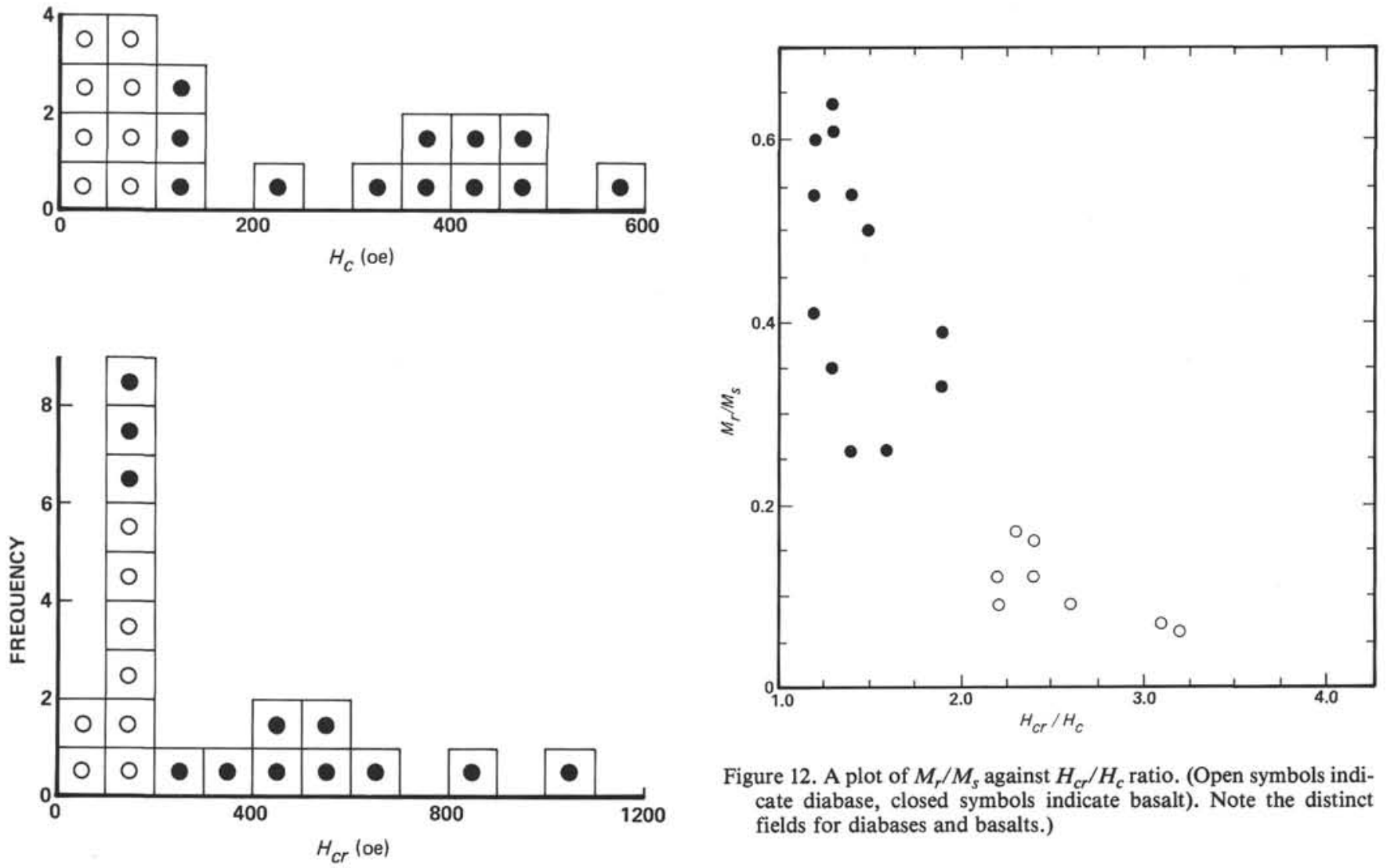

Figure 12. A plot of $M_{r} / M_{s}$ against $H_{c r} / H_{c}$ ratio. (Open symbols indicate diabase, closed symbols indicate basalt). Note the distinct fields for diabases and basalts.)

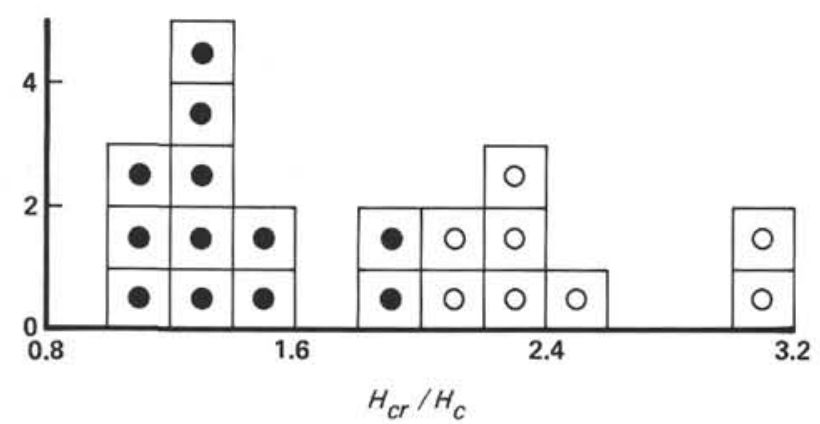

Figure 11. Histograms of coercive force $\left(H_{c}\right)$, remanent coercive force $\left(H_{c r}\right)$, and $H_{c r} H_{c}$ ratio. (Filled symbols are basalts, open symbols diabases.)

results (Fig. 13) show a considerable scatter similar to that observed by Lowrie and Israfil (1974), Lowrie and Hayes (1975), Kent and Opdyke (1976), and Kent and Lowrie (1977). Figure 14 shows a plot of $\chi$ versus $M_{s}$. We see that these two parameters are positively correlated, which suggests that the primary reason for variation in $M_{s}$ and $\chi$ is variation in magnetic mineral content.

\section{Thermomagnetic Curve and Curie Temperature, $T_{c}$}

We conducted thermomagnetic experiments by measuring the temperature dependence of the strong-field magnetization $\left(M_{s}\right)$ with a vibrating sample magnetom-

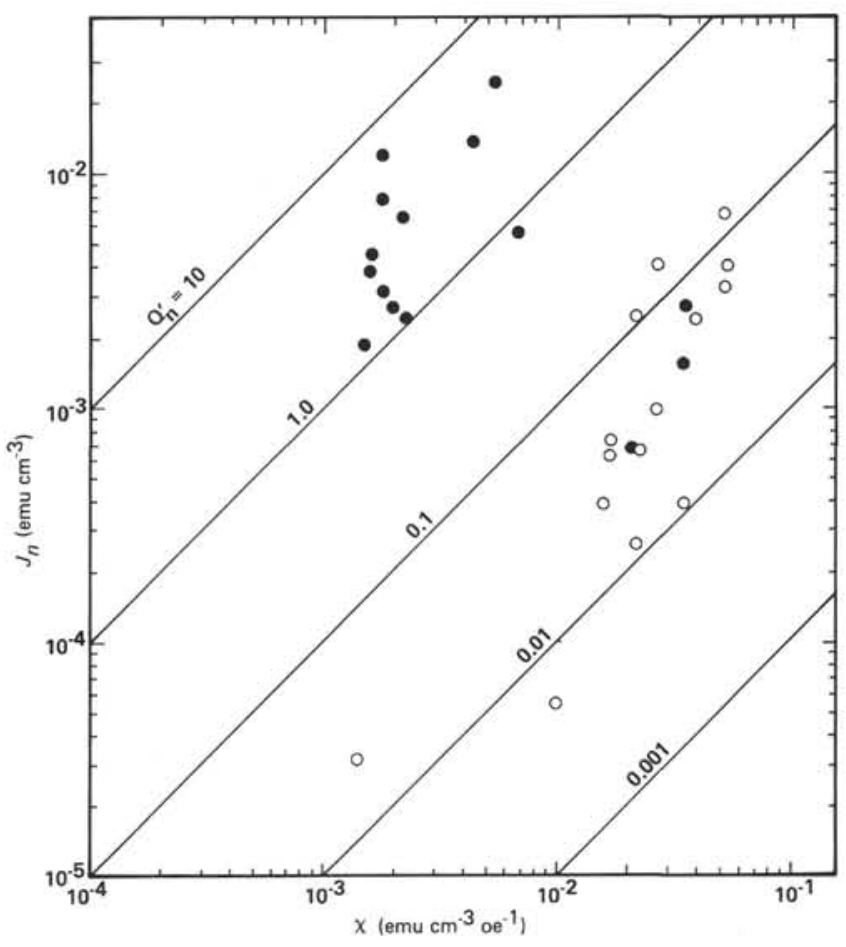

Figure 13. A plot of NRM intensity $\left(J_{n}\right)$ against weak-field susceptibility $(\chi)$. (The diagonal lines are for different modified Koenigsberger ratios $\left[Q_{n}^{\prime}\right]$. Open symbols signify diabase, closed symbols basalt.) 


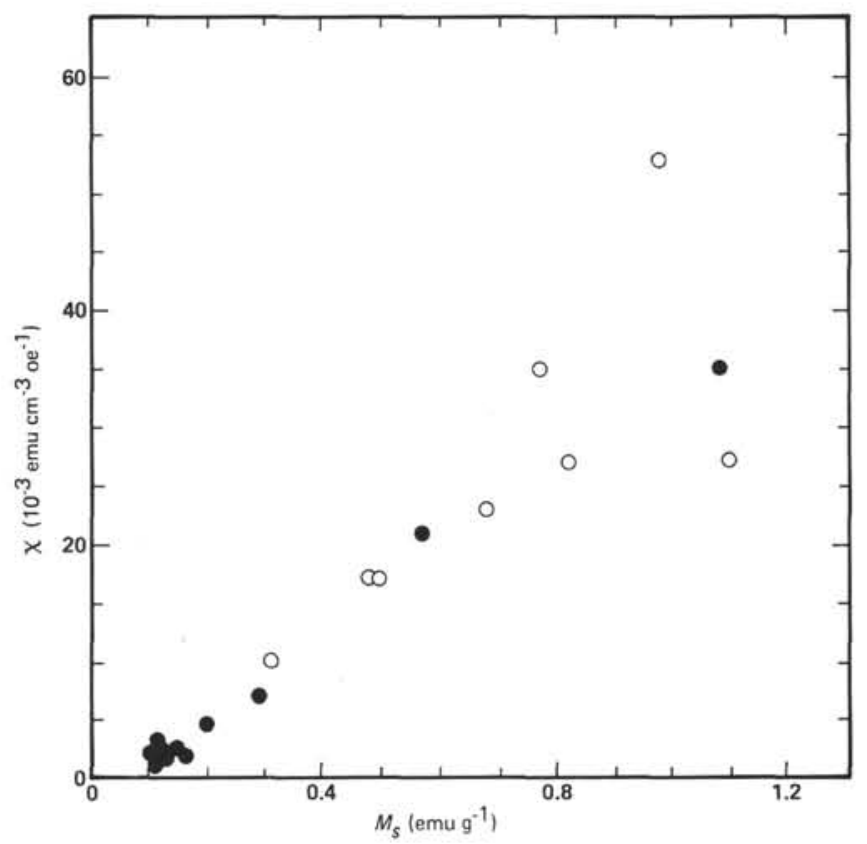

Figure 14. A plot of weak-field susceptibility $(\chi)$ against saturation magnetization $\left(M_{s}\right)$. Note the positive correlation between these two properties.)

eter. We used whole rock powders ground from small chips taken from each specimen and heated in vacuum in the presence of a strong magnetic field of $2.5 \mathrm{koe}$. The heating and cooling rates used vary from $2.5^{\circ} \mathrm{C} /$ min to $20^{\circ} \mathrm{C} / \mathrm{min}$. Both the temperature and the magnetization measurements have been calibrated using standard specimens.

We must mention that there is an appreciable time lag between the actual temperature of the sample and the temperature read by thermocouple; this time lag increases considerably at higher heating and cooling rates. The corrections applied at $20^{\circ} \mathrm{C} / \mathrm{min}$ are therefore only approximate. We have thus reported in Table 2. the $T_{c} \mathrm{~s}$ obtained at lower rates of 2.5 to $10^{\circ} \mathrm{C} / \mathrm{min}$. Wherever values of $T_{c}$ are reported for $20^{\circ} \mathrm{C} / \mathrm{min}$., they must be considered only approximate values.

Figure 15 shows typical thermomagnetic curves, whereas Table 2 lists the salient characteristics of all samples. Table 4 gives site mean properties. The observed range of Curie temperatures is similar to that commonly observed in oceanic basalts (Hall and Ryall, 1977; Johnson and Hall, 1978; Marshall, 1978; Hamano et al., 1979). These authors have also inferred a rather narrow range of composition of the original titanomagnetites in oceanic basalts $\left(x=0.55 \sim 0.68\right.$ in $x \mathrm{Fe}_{2} \mathrm{TiO}_{4}$ $\left.(1-x) \mathrm{Fe}_{3} \mathrm{O}_{4} ; T_{c}=120^{\circ} \mathrm{C} \sim 150^{\circ} \mathrm{C}\right)$. Such samples containing "unoxidized" titanomagnetites show reversible $M_{s}$ versus $T$ curves (e.g., Ozima and Ozima, 1971). These titanomagnetites suffer oxidation at ambient seawater temperatures to (cation deficient) titanomaghemites. The $T_{c}$ of this phase increases with increasing degree of oxidation up to temperatures of about 400 to $470^{\circ} \mathrm{C}$ (Readman and O'Reilly, 1972; Hall and Ryall, 1977).
The diabases from Site 473 show reversible (or slightly irreversible) thermomagnetic curves. Their $T_{c}$ ranges from $135^{\circ} \mathrm{C}$ to about $185^{\circ} \mathrm{C}$. Thus these diabases seem to contain titanomagnetites with a rather low degree of oxidation $(Z=0 \sim 0.4$; Readman and O'Reilly, 1972; Hall and Ryall, 1977). The basalt sample studied from Site 473 also shows a reversible $M_{s}$ versus $T$ curve but a slightly higher $T_{c}\left(217^{\circ} \mathrm{C}\right)$, suggesting a slightly greater degree of oxidation of its titanomagnetites.

All the other basalts (Holes 467, 470, 470A, and 472) as well as the diabases from Hole 469 show irreversible $M_{s}$ versus $T$ curves with initial Curie temperatures ranging from $287^{\circ} \mathrm{C}$ to $457^{\circ} \mathrm{C}$. So these basalts seem to be characterized by higher degrees of cation deficiency. The irreversibility in their thermomagnetic curves results from the unmixing upon heating (in vacuum) of their titanomaghemites to different proportions of highly magnetic titanium-poor titanomagnetites and to relatively nonmagnetic titanium-rich phases (e.g., Johnson and Merrill, 1973).

The altered diabases from Site 471 , on the other hand, show reversible (or slightly irreversible) $M_{s}$ versus $T$ curves, but their Curie temperatures are considerably higher $\left(T_{c}=505^{\circ} \mathrm{C}-525^{\circ} \mathrm{C}\right)$. Hall and Ryall (1977) have observed high $T_{c}\left(>470^{\circ} \mathrm{C}\right)$ in some DSDP basalt samples and have attributed them either to high-temperature, initial-cooling oxidation of some samples resulting in the phase splitting of the original titanomagnetites to magnetite and ilmenite (magnetite being responsible for high $T_{c}$ ) or, for other samples, to phase splitting of unstable oxides during laboratory thermal cycling. Other authors (e.g., Butler et al., 1976; Banerjee et al., 1977; Banerjee, 1980) have also suggested that extrusives with $T_{c}>500^{\circ} \mathrm{C}$ and reversible $M_{s}$ versus $T$ curves might represent normal spreading center processes, caused by reheating due to contact metamorphism and/or hydrothermal circulation. The cause of such high $T_{c}\left(>500^{\circ} \mathrm{C}\right)$ in the diabases of Site 471 is, however, not quite clear at present but is perhaps related to their alteration itself.

We have investigated the thermomagnetic properties of some selected samples in somewhat greater detail. Figure 16 gives the corresponding $M_{s}$ versus $T$ curves.

We have obtained two thermomagnetic curves for a basalt sample from Site 469 (Sample 469-46-2, 23-25 $\mathrm{cm})$ at two different heating-cooling rates $\left(10^{\circ} \mathrm{C}\right.$ and $20^{\circ} \mathrm{C} / \mathrm{min}$; Fig. 16; A and B). When we heated the sample at the slower rate of $10^{\circ} \mathrm{C} / \mathrm{min}$., we observed a welldeveloped unmixing reaction peak in the $M_{s}$ versus $T$ heating cycle. After the initial Curie temperature of $\sim 331^{\circ} \mathrm{C}$ was reached and we continued to heat the sample, $M_{s}$ began increasing until its Curie temperature of $\sim 483^{\circ} \mathrm{C}$ was reached. Upon cooling, we observed (besides the $T_{\mathrm{c}}$ of $\sim 483^{\circ} \mathrm{C}$ ) another much lower Curie temperature $\left(\sim 139^{\circ} \mathrm{C}\right)$. The final saturation magnetization $\left(M_{s}^{f}\right)$ remained much lower than its initial saturation magnetization $\left(M_{s}^{i}\right)$, i.e., $M_{s}^{f}<M_{s}^{i}$. This means that the phase splitting has been such that the sum of final phases (highly magnetic titanium-poor magnetite and 

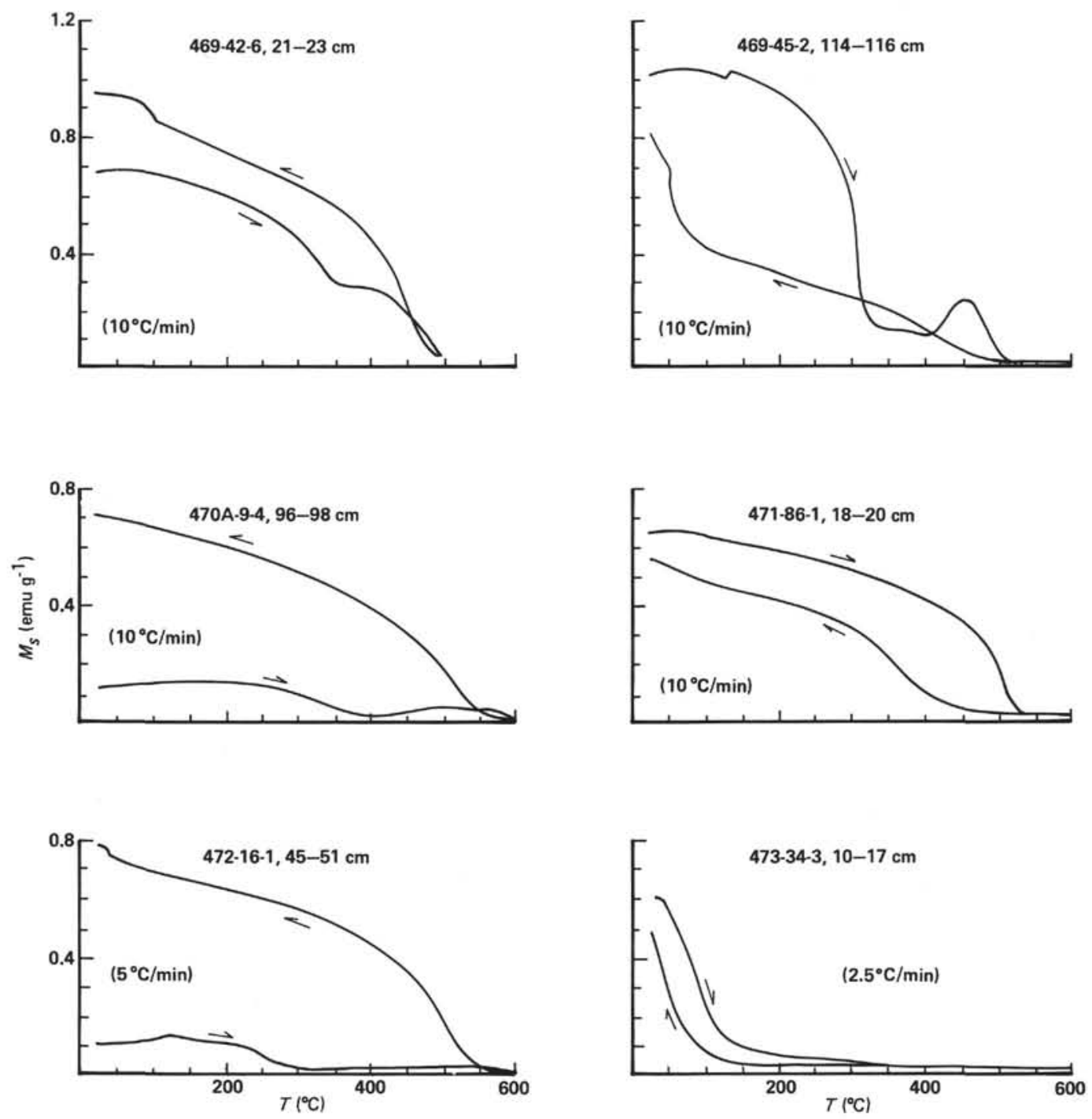

Figure 15. Typical thermomagnetic curves. (Heating and cooling cycles are indicated by arrows $[-$ and - , respectively]. Heating and cooling rates are also given in parentheses.)

weakly magnetic titanium-rich ilmenite) has a lower $M_{s}^{f}$ than the initial titanomaghemite. Thus unmixing favored the weakly magnetic titanium-rich phase. In the second experiment (Fig. 16, B), we heated a new fraction of the sample at the faster rate of $20^{\circ} \mathrm{C} / \mathrm{min}$. No unmixing peak was visible at this point and $M_{s}^{f}>M_{i}^{s}$. $T_{c}$ from the heating cycle was $\approx 317^{\circ} \mathrm{C}$ and $T_{c}$ from the cooling cycle was $\approx 516^{\circ} \mathrm{C}$. In this run, it appears that the unmixing favored the highly magnetic titanium-poor phase. However, it is also possible that in both cases unmixing resulted in the formation of titanium-poor phases. But when the heating-cooling rates were slow, during the cooling cycle a new titanium-poor phase was synthesized in the sample holder because of the presence of highly reducing organic vapor from backstreaming in the diffusion pump.

We conducted a repeated thermal cycling experiment on a basalt from Hole 470A (Sample 470A-7-3, 76-78 cm; Fig. 16,C and D). When first heated (Fig. 16, C), this sample showed a well-developed unmixing peak in its heating cycle. On cooling, it showed a "concavetype" cooling curve, signifying perhaps a continuous range of Curie temperatures. When we reheated this "heated" sample (Fig. 16, D), the concave-type curve persisted and the new cycle proved to be reversible. Hamano et al. (1979) have conducted a similar experiment on a basalt sample and have found that the low Curie temperature phase increased by repeated heating.

We further tested the slight irreversibility observed in thermomagnetic curves of altered diabases from Site 471 . When we heated the sample $(471-88-3,82-84 \mathrm{~cm})$ up to $600^{\circ} \mathrm{C}$, we obtained a slightly irreversible curve (Fig. 16, E) whose $M_{s}^{f}<M_{s}^{i}$. In order to determine whether heating beyond $\sim 500^{\circ} \mathrm{C}\left(500-600^{\circ} \mathrm{C}\right.$ interval) caused this difference in $M_{s}$, we conducted another thermomagnetic experiment on a new fraction of this sample. This time we heated the sample only up to $T_{c}$ $\left(\sim 506^{\circ} \mathrm{C}\right)$ and obtained a similar relationship of $M_{s}^{i}$ and 
Table 4. Average hysteresis and thermomagnetic characteristics of Leg 63 sites.

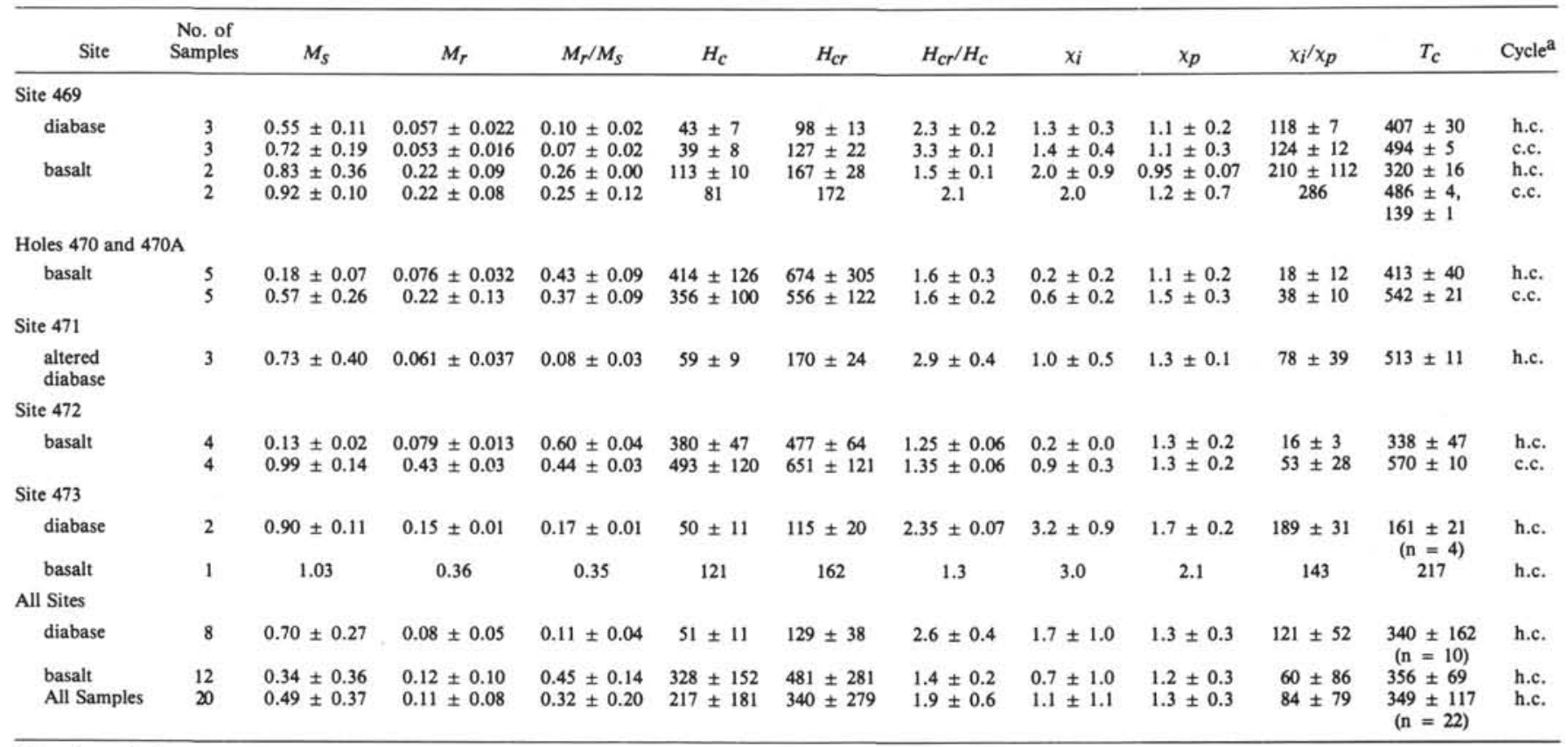

${ }^{a}$ Heating cycle (h.c.) or cooling cycle (c.c.).

$M_{s}^{f}$ (Fig. 16, F). This indicates that whatever change resulted, it took place during the heating up to $T_{c}$ itself; heating beyond this temperature did not cause any further change.

We chose a sample from Site 472 (472-14-1, 145-150 $\mathrm{cm}$ ) for a more detailed study. This sample showed marked color differences between its margin (rim) and core, indicating its margin to be slightly more altered than its core (Hart et al., 1974); Terrell et al., 1979). We divided this sample into two specimens-"core" and "margin" and conducted thermomagnetic experiments on the two subsamples. We observed that the Curie temperatures were almost identical and so were the general shapes of the curves (Fig. 16, G and H). Thus we did not observe any appreciable differences in their thermomagnetic properties. We should mention that these specimens show some noticeable chemical differences but indistinguishable (within analytical errors) ${ }^{87} \mathrm{Sr} /{ }^{86} \mathrm{Sr}$ ratios (see Verma, this volume).

Finally, let us describe the results of further experiments on a diabase from Site 473 (473-32-1, 77-84 $\mathrm{cm})$. When we heated the sample up to $600^{\circ} \mathrm{C}-\mathrm{far}$ beyond its $T_{c}\left(\sim 189^{\circ} \mathrm{C}\right.$; Fig. 16, I)-we observed a slightly irreversible curve whose $M_{s}^{f}<M_{s}^{i}$. When reheated, this sample showed reversibility, implying that whatever change took place did so in the first experiment. In order to determine during what temperature interval the change that caused $M_{s}^{f}<M_{s}^{i}$ took place, we conducted another experiment with a new fraction of the sample. This time we heated the sample only up to $\sim 250^{\circ} \mathrm{C}$ and found that $M_{s}^{f}=M_{s}^{i}$ (Fig. 16, J). There is a reversible behavior in this sample when heated to lower temperatures. Thus this sample shows a different behavior (Fig. 16, I and J) than does the sample from Site 471 (Fig. 16, E and F).

\section{CONCLUSIONS}

We have measured several magnetic properties of igneous rocks from Sites 469 through 473 . The NRM intensity $\left(J_{n}\right)$ ranges from 0.031 to $24.5 \times 10^{-3} \mathrm{emu} \mathrm{cm}^{-3}$. Stable inclinations $(I)$ are apparently obtainable for all sites except Site 473. ARM acquisition experiments show that the NRM of basalts from Site 470 may largely be the original TRM. Detailed VRM experiments do not confirm the conclusion of Lowrie and Kent (1975) that the VRM superposed on NRM can develop twice as rapidly as on a sample in the AF-demagnetized state. These experiments also show that the VRM component of the NRM of basalts from Sites 470 and 472 is quite small, whereas the samples from other sites $(469,471$, and 473 ) are highly viscous. The diabases and basalts are distinguishable on the basis of several magnetic properties. The most useful parameters for this purpose seem to be $M_{r} / M_{s}$ and $H_{c r} / H_{c}$ ratios.

These samples have rather high values of weak-field susceptibility $(\chi)$, compared to most oceanic igneous rocks studied. The weak-field susceptibility $(\chi)$ is positively correlated with the saturation magnetization $\left(M_{s}\right)$.

Thermomagnetic measurements reveal the presence of both reversible (or slightly irreversible) and irreversible curves. The Curie temperature ranges from $135^{\circ} \mathrm{C}$ to $525^{\circ} \mathrm{C}$. These studies also throw further light on the unmixing processes that result from heating (even in vacuum) and that give rise to the diversity of thermomagnetic curves.

\section{ACKNOWLEDGMENTS}

The first author (SPV) appreciates the opportunity to participate on board during Leg 63 of the Deep Sea Drilling Project. He further expresses his thanks to V. Rama Murthy for making his visit to the 


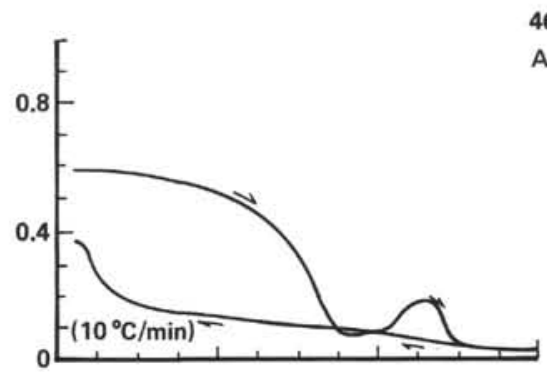

$469-46-2,23-25 \mathrm{~cm}$

A

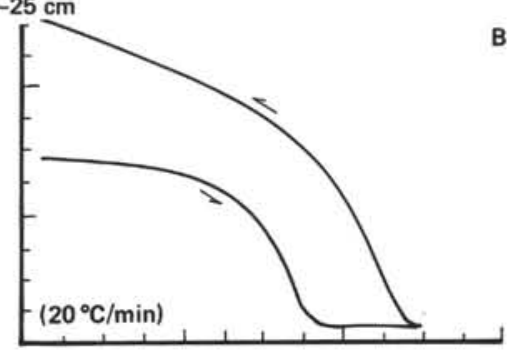

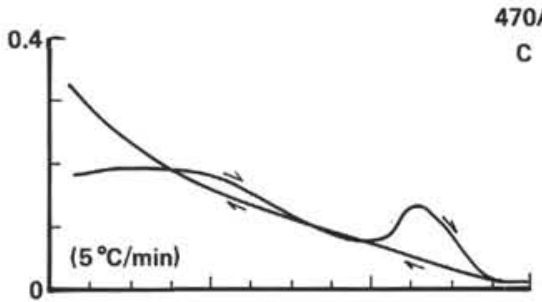

$470 \mathrm{~A}-7-3,76-78 \mathrm{~cm}$
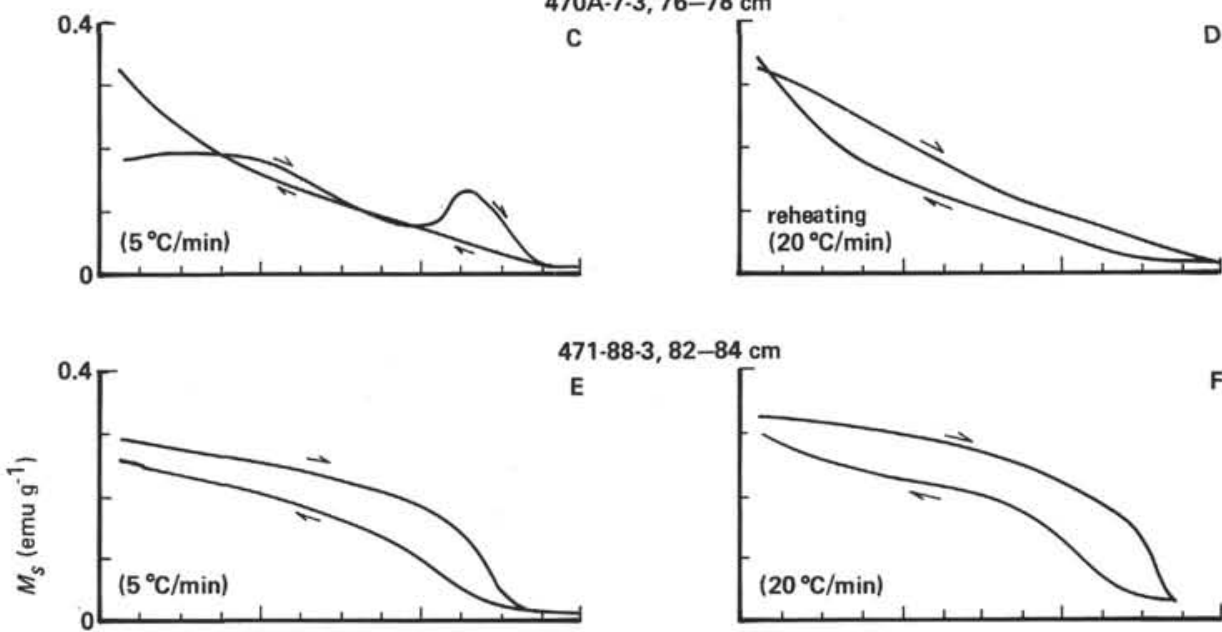

$88-3,82-84 \mathrm{~cm}$

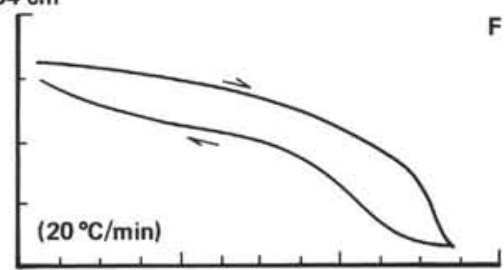

$472-14-1,145-150 \mathrm{~cm}$
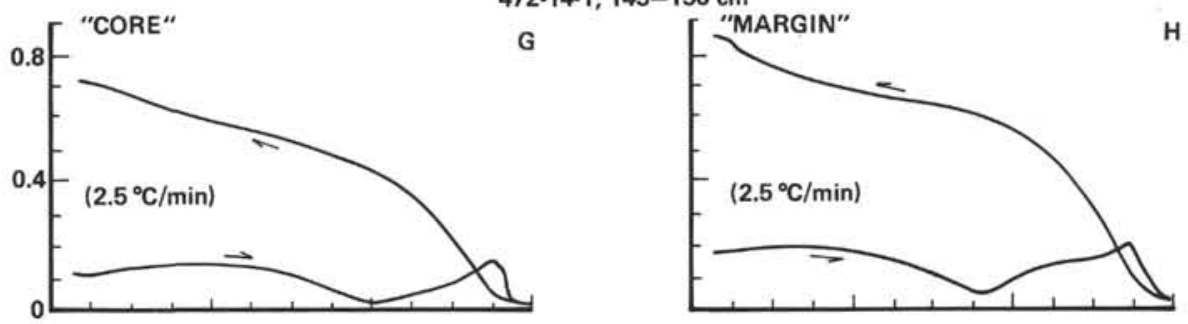

G

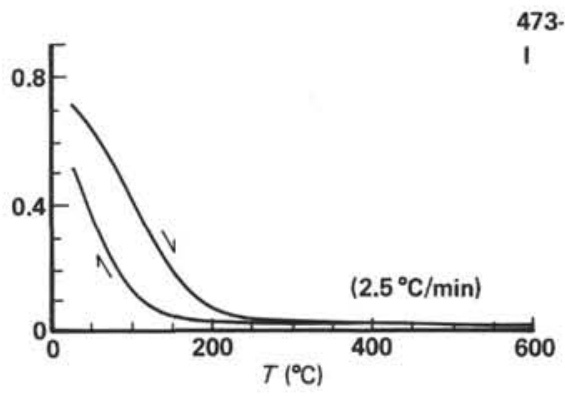

473-32-1, 77-84 cm

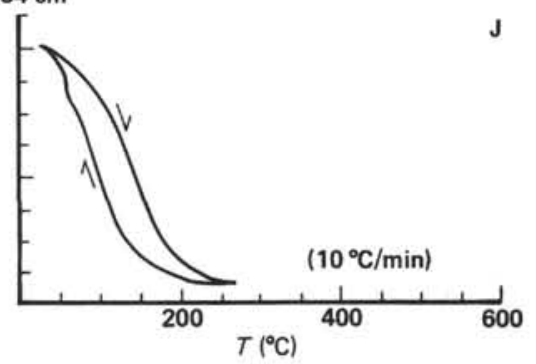

Figure 16. Detailed thermomagnetic characteristics for selected samples. A and B. Effect of different heating-cooling rates. C and D. Reheating (D) of a sample that was heated earlier (C). E and F. Heating to different maximum temperatures. G and H. Comparison of a "core"-"margin" pair. I and J. Heating to different maximum temperatures.

Department of Geology and Geophysics possible. Finally, he appreciates the help of several colleagues at the Rock Magnetism Laboratory (at the University of Minnesota), especially Jim Marvin, Dave Bogdan, and Bruce Moskowitz, in familiarizing him with the equipment and procedures used in their laboratory. We are grateful to $\mathrm{J}$. Urrutia F., D. V. Kent, and K. Pisciotto for helpful comments.

\section{REFERERENCES}

Ade-Hall, J. M., Johnson, H. P., and Ryall, P. J. C., 1976. Rock magnetism of basalts, Leg 34. In Hart, S. R., Yeats, R. S., et al., Init. Repts. DSDP, 34: Washington (U.S. Govt. Printing Office), 459-468. 
Banerjee, S. K., 1980. Magnetism of the oceanic crust: evidence from ophiolite complexes. J. Geophys. Rev., 85:3557-3566.

Banerjee, S. K., Levi, S., and Bogdan, D., 1977. Observations of nearly pure magnetite in the upper oceanic crust-implications for thermal regime at a spreading center. EOS, Trans. Am. Geophys. Union, 58:379.

Beske-Diehl, S., and Banerjee, S. K., 1979. An example of magnetic properties as indicators of alteration in ancient oceanic lithosphere-the Othris ophiolite. Earth Planet. Sci. Lett., 44:451-462.

Brecher, A., Atwater, T., Stein, J., et al., 1977. Some magnetic properties of some Leg 37 samples. In Aumento, F., Melson, W. G., et al., Init. Repts. DSDP, 37: Washington (U.S. Govt. Printing Office), 465-469.

Butler, R. F., Banerjee, S. K., and Stout, J. H., 1976. Magnetic properties of oceanic pillow basalts: evidence from Macquarie Island. Geophys. J. R. Astron. Soc., 47:179-196.

Day, R., Fuller, M., and Schmidt, V. A., 1977. Hysteresis properties of titanomagnetite: grain size and composition dependence. Phys. Earth Planet. Inter., 13:260-267.

Day, R., Halgedahl, S., Steiner, M., et al., 1979. Magnetic properties of basalts from DSDP Leg 49. In Luyendyk, B. P., Cann, J. R., et al., Init. Repts. DSDP, 49: Washington (U.S. Govt. Printing Office), 781-791.

Dunlop, D. J., 1972. Magnetite: behavior near the single-domain threshold. Science, 176:41-43.

Dunlop, D. J., and West, G. F., 1969. An experimental evaluation of single domain theories. Rev. Geophys. Space Phys., 7:709-757.

Gillingham, D. E. W., and Stacey, F. D., 1971. Anhysteretic remanent magnetization (A.R.M.) in magnetite grains. Pure Appl. Geophys., 91:160-165.

Grommé, S., and Mankinen, E., 1976. Natural remanent magnetization, magnetic properties, and oxidation of titanomagnetite in basaltic rocks from DSDP Leg 34. In Yeats, R. S., Hart, S. R., et al., Init. Repts. DSDP, 34: Washington (U.S. Govt. Printing Office), 485-494.

Hall, J. M., and Ryall, P. J. C., 1977. Rock magnetism of basement rocks, Leg 37. In Aumento, F., Melson, W. G., et al., Init. Repts. DSDP, 37: Washington (U.S. Govt. Printing Office), 489-501.

Hamano, Y., Nishitani, T., and Kono, M., 1979. Magnetic properties of basalt samples from Deep Sea Drilling Project Holes 417D and 418A. In Donnelly, T., Francheteau, J., Bryan, W., Robinson, P., Flower, M., Salisbury, M., et al., Init. Repts. DSDP, 51, 52, 53, Pt. 2: Washington (U.S. Govt. Printing Office), 791-814.

Hart, S. R., Erlank, A. J., and Kable, E. J. D., 1974. Sea floor basalt alteration: some chemical and $\mathrm{Sr}$ isotopic effects. Contrib. Mineral. Petrol., 44:219-230.

Honnorez, J., Böhlke, J. K., Honnorez-Guerstein, B. M., et al., 1978. Correlation between the changes in the mineralogy, chemistry, and magnetic properties of basalts from DSDP Leg 46 with low temperature submarine alteration. In Dimitriev, L., Heirtzler, J., et al., Init. Repts. DSDP, 46: Washington (U.S. Govt. Printing Office) $371-376$

Johnson, H. P., 1978. Rock magnetic properties of igneous rock samples-Leg 45. In Melson, W. G., Rabinowitz, P. D., et al., Init. Repts. DSDP, 45: Washington (U.S. Govt. Printing Office), 397406.

Johnson, H. P., and Hall, J. M., 1978. A detailed rock magnetic and opaque mineralogy study of the basalts from the Nazca Plate. Geophys. J. R. Astron. Soc., 52:45-64.
Johnson, H. P., and Merrill, R. T., 1973. Low temperature oxidation of a titanomagnetite and the implications for paleomagnetism. $J$. Geophys. Res., 78:4938-4949.

Kent, D. V., and Lowrie, W., 1977. VRM studied in Leg 37 igneous rocks. In Aumento, F., Melson, W. G., et al., Init. Repts. DSDP, 37: Washington (U.S. Govt. Printing Office), 525-529.

Kent, D. V., and Opdyke, N. D., 1976. Paleomagnetism and magnetic properties of igneous rock samples-Leg 38. In Talwani, M., Udintsev, G., et al., Init. Repts. DSDP, Suppl. to Vols. 38, 39,40 , and 41: Washington (U.S. Govt. Printing Office), 3-8.

Kono, M., 1978. Reliability of paleointensity methods using alternating field demagnetization and anhysteretic remanence. Geophys. J. R. Astron. Soc., 54:241-261.

Levi, S., 1973. Comparison of some ARM and TRM properties in magnetites. EOS, Trans. Am. Geophys. Union, 54:1071.

Levi, S., Banerjee, S. K., Beske-Diehl, S., et al., 1978. Limitations of ophiolite complexes as models for the magnetic layer of the oceanic lithosphere. Geophys. Res. Lett., 5:473-476.

Levi, S., and Merrill, R. T., 1976. A comparison of ARM and TRM in magnetite. Earth Planet. Sci. Lett., 32:171-184.

Lowrie, W., 1974. Oceanic basalt magnetic properties and the Vine and Matthews hypothesis. J. Geophys., 40:513-536.

Lowrie, W., and Hayes, D. E., 1975. Magnetic properties of oceanic basalt samples. In Hayes, D. E., Frakes, L. A., et al., Init. Repts. $D S D P, 28$ : Washington (U.S. Govt. Printing Office), 869-878.

Lowrie, W., and Israfil, M. N., 1974. Paleomagnetism of basalt samples from Leg 29. In Kennett, J. P., Houtz, R. E., et al., Init. Repts. DSDP, 29: Washington (U.S. Govt. Printing Office), 11091115.

Lowrie, W., and Kent, D. V., 1975. Viscous remanent magnetization in basalt samples. In Hart, S. R., Yeats, R. S., et al., Init. Repts. DSDP, 34: Washington (U.S. Govt. Printing Office), 479-484.

Lowrie, W., Løvlie, R., and Opdyke, N. D., 1973. The magnetic properties of Deep Sea Drilling Project basalts from the Atlantic Ocean. Earth Planet. Sci. Lett., 17:338-349.

Marshall, M., 1978. The magnetic properties of some DSDP basalts from the North Pacific and inferences for Pacific plate tectonics. J. Geophys. Res., 83:289-308.

Ozima, M., and Ozima, M., 1971. Characteristic thermomagnetic curves in submarine basalts. J. Geophys. Res., 76:2051-2056.

Parry, L. C., 1965. Magnetic properties of dispersed magnetite powders. Philos. Mag., 11:303-312.

Petersen, N., 1978. Rock- and paleomagnetism of basalts from Sites 396B, Leg 46. In Dmitriev, L., Heirtzler, J., et al., Init. Repts. DSDP, 46: Washington (U.S. Govt. Printing Office), 357-362.

Petersen, N., Bleil, U., and Eisenach, P., 1978. Rock and paleomagnetism of Leg 42A, Hole 373A basalts. In Hsü, K. J., Montadert, L., et al., Init. Repts. DSDP, 42, Pt. 1: Washington (U.S. Govt. Printing Office), 881-886.

1979. Rock- and paleomagnetism of Leg 43 basalts. In Tucholke, B. E., Vogt, P. R., et al., Init. Repts. DSDP, 43: Washington (U.S. Govt. Printing Office), 773-780.

Readman, P. W., and O'Reilly, W., 1972. Magnetic properties of Oxidized (cation deficient) titanomagnetites $(\mathrm{Fe}, \mathrm{Ti}, \square)_{3} \mathrm{O}_{4} . J$. Geomagn. Geoelectr., 24:69-90.

Terrell, D. J., Pal, S., López M., M., et al., 1979. Rare-earth elements in basalt samples, Gulf of California. Chem. Geol., 26:267-275. 